\title{
Haukur IngVarsson
}

\section{Frá suðri til norðurs}

\section{William Faulkner og Guðmundur Daníelsson}

\author{
„Fortíðin er hér á ferðinni í kvöld. Svo sannarlega, hið liðna er enn \\ ekki liðið. Рað prjóskazt við, hangir við hlutina og vill ekki sleppa.“ \\ Guðmundur Daníelsson, Afjörðu ertu kominn: Eldur, 1941
}

„The past is never dead. It's not even past.“

William Faulkner, Requiem for a Nun, $1951^{1}$

\section{$I$}

Í byrjun fjórða áratugarins hafði bandaríski rithöfundurinn William Faulkner skrifað fimm skáldsögur, m.a. The Sound and the Fury (1929) og As I Lay Dying (1930) sem í dag eru taldar meðal helstu afreka í skáldsagnagerð á 20. öld. Samtímamenn hans voru fæstir á sama máli og pó gagnrýnendur hafi hælt verkum hans pegar pau komu út fyrir tilraunakennda byggingu, frumlegan stíl og nýstárlega frásagnartækni pá seldust pær illa í heimalandinu og pví gekk honum erfiðlega að sjá sér og sínum farborða með ritstörfum. ${ }^{2}$ Á sama tíma fór áhugi á bandarískum bókmenntum vaxandi í Evrópu og virðing fyrir peim sömuleiðis. Árið 1930 er gjarna látið marka ákveðin tímamót pegar staða bandarískra bókmennta er metin í alpjóðlegu samhengi en pá hlaut Sinclair Lewis Nóbelsverðlaunin í bókmenntum fyrstur Banda-

1 William Faulkner, Requiem for a Nun, William Faulkner: Novels 1942-1954, New York: The Library of America, 1985, bls. 471-664, hér bls. 535.

2 M. Thomas Inge, „Introduction“, William Faulkner: The Contemporary Reviews, ritstj. M. Thomas Inge, The American Critical Archives, Cambridge: Cambridge University Press, 1995, bls. xiii.

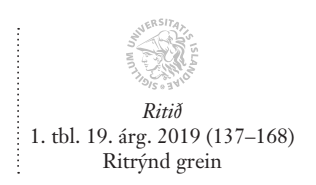

(C) 2019 Ritið, tímarit Hugvísindastofnunar og höfundur greinarinnar

Útgefandi:

Hugvísindastofnun Háskóla Íslands, Sæmundargötu 2, 101 Reykjavík
Birtist á vefnum http://www.ritid.hi.is. Tengiliður: ritið@hi.is

DOI: $10.33112 /$ ritid.19.1.7

Birt samkvæmt skilmálum Creative Commons BY (4.0). 
ríkjamanna. ${ }^{3}$ Í kjölfarið fjölgaði pýddum og útgefnum verkum eftir bandaríska höfunda enn frekar í Evrópu. Faulkner var einn af peim sem barst með pessari bandarísku bylgju en pýðingar á verkum hans á frönsku, sem hófust árið 1932, voru mikilvægur áfangi á leið hans inn á hið alpjóðlega svið bókmenntanna og stundum er jafnvel látið í veðri vaka að vinsældir hans í Frakklandi hafi leitt til pess að hann hlaut Nóbelsverðlaunin í bókmenntum árið 1950. ${ }^{4}$ Pá vill gleymast að menntamenn á Norðurlöndum tóku snemma að gefa pessum lítt kunna bandaríska rithöfundi gaum. Pannig skrifaði sænska skáldið Artur Lundkvist fimm síðna grein um Faulkner í tímaritið Bonniers Litterära Magasin árið 1932 sem fylgdi úr hlaði býðingu hans á smásögunni „A Rose for Emily“ eða „En ros åt Emily“. ${ }^{5}$ Ári síðar kom skáldsagan Soldiers' Pay (1926) út í Noregi í ritröðinni Gyldendals moderne romanserie undir heitinu Soldatens Sold (1933) og Light in August (1932) eða Mørk august (1934) ári síðar. ${ }^{6}$ Ritstjóri norsku ritraðarinnar, Sigurd Hoel,

Gisèle Sapiro, „Faulkner in France: Or How to Introduce a Peripheral Unknown Author in the Center of the World Republic of Letters", Fournal of World Literature 1: 3/2016, bls. 391-411, hér bls. 394. Í ræðunni sem Sinclair Lewis flutti við afhendingu Nóbelsverðlaunanna sýndi hann bandarískum kollegum sínum mikið örlæti. Lyfti hann verkum peirra og lagði áherslu á pau áhrif sem peir höfðu haft á hann. Á sama tíma gagnrýndi hann bandarískt samfélag harðlega á sömu forsendum og margir evrópskir menntamenn höfðu gert í gegnum tíðina. Sumir höfundanna sem Lewis nefndi voru eldri en hann sjálfur og höfðu skapað sér nafn t.d. Upton Sinclair, Sherwood Anderson og Willa Cather, aðrir voru yngri og lítt pekktir jafnt heima sem heiman. Í peim hópi mætti telja Thomas Wolfe, Michael Gold og William Faulkner. Sjá, Sinclair Lewis, „Nobel Lecture: The American Fear of Literature“, sótt 3. apríl 2019 af http://www.nobelprize.org/nobel_prizes/literature/ laureates/1930/lewis-lecture.html.

4 Pascale Casanova, The World Republic of Letters [La république mondiale des lettres], pýðandi M.B. DeBevoise, Cambridge, Massachusetts/London, England: Harvard University Press, 2004, bls. 131. Faulkner hlaut strangt tiltekið Nóbelsverðlaunin í bókmenntum fyrir árið 1949 en hann tók ekki við peim fyrr en 1950.

5 Grein Lundkvists er sú fyrsta sem fjallar sérstaklega um Faulkner og verk hans í Svípjóð. Artur Lundkvist, „William Faulkner“, Bonniers litterära magasin 1: 6/1932, bls. 6-10. Nafn Faulkners hafði pó borið á góma í umfjöllun um bandarískar bókmenntir. Mats Jansson, „Swedish Modernism“, Modernism, ritstj. Ástráður Eysteinsson og Vivian Liska, Amsterdam/Philadelphia: John Benjamins Publishing Company, 2007, bls. 837-845, hér bls. 840. Um viðtökur verka William Faulkners í Svípjóð sjá, Janson, Mats, „In the Treces of Modernism: William Faulkner in Swedish Criticism 1932-1950“, Humanities 7: 4/2018, bls. 96-128.

6 Hans Heiberg pýddi Soldatens sold en Mørk august pýddi ritstjórinn Sigurd Hoel. 
skrifaði inngang að báðum pýðingunum en Soldatens Sold er fyrsta pýðingin á skáldsögu eftir Faulkner í heiminum.?

Sumarið 1936 fór íslenski rithöfundurinn Guðmundur Daníelsson í menningarreisu til Kaupmannahafnar. Par komst hann í kynni við norsku býðingarnar á skáldsögum Faulkners. ${ }^{8}$ Lestur peirra hafði varanleg áhrif á Guðmund eins og sjá má á viðtali sem birtist við hann í Tímanum pann 28. september 1939. Í niðurlagi pess er Guðmundur inntur eftir áhrifavöldum og lýkur hann peirri yfirferð á pví að nefna „yngstu höfunda Ameríkumanna“. Hann kýs pó aðeins að nafngreina William Faulkner sem hann segir: „tvímælalaust með mestu skáldum heimsins í dag.“9 Guðmundur var, pegar parna var komið sögu, farinn að leggja drög að príleik sem kom út á fyrri hluta fimmta áratugarins en hann samanstendur af skáldsögunum $A f$ jörðu ertu kominn: Eldur (1941), Sandur (1942) og Landið handan landsins (1944). ${ }^{10}$ Pó bæði Guðmundur og aðrir hafi síðan haft orð á pví að augljós skyldleikamerki séu með verkum hans og Faulkners hefur aldrei verið gerð nákvæm grein fyrir pví í hverju líkindin eru fólgin. ${ }^{11}$ Pví má við petta bæta að pó Faulkner hafi heimsótt Ísland árið 1955, smásögur hans verið býddar á íslensku auk priggja skáldsagna og íslenskir höfundar eins og Thor Vil-

7 Um viðtökur Faulkners og verka hans í Noregi sjá, Hans H. Skei, „The Reception and Reputation of William Faulkner in Norway, 1932-1982“, Notes on Mississippi Writers XVI: 1 \& 2/1984, bls. 25-58.

8 Guðmundur Daníelsson, „,Gegnum lystigarðinn“: Eftirmáli með 2. útgáfu“, Gegnum lystigarðinn, Reykjavík: Isafoldarprentsmiðja H.F., 1965, bls. 187-191, hér bls. 188 .

9 „Viðtal við rithöfund: Guðmundur Daníelsson frá Guttormshaga segir pætti úr æfisögu sinni“, Tíminn, 28. september 1939. Pýðingar á verkum Faulkners í Danmörku hófust árið 1939 en bókmenntaáhugamenn par í landi virðast hafa fylgst grannt með útgáfu bóka í Noregi og Svípjóð. Um viðtökur Faulkners og verka hans í Danmörku sjá, Jan Nordby Gretlund, „William Faulkner's Strange Career in Danish“, Notes on Mississippi Writers XVIII: 1/1986, bls. 35-52.

10 Framvegis verður skáldsagan Af jörðu ertu kominn: Eldur kölluð Eldur í meginmáli. Aftur á móti er vísað til príleiksins í heild sinni sem Afjörðu ertu kominn. Tilvísanir í Eld birtast í meginmáli innan sviga og titillinn einfaldlega skammstafaður E á undan blaðsíðutali. Vísað er til Landsins handan landsins með sama fyrirkomulagi en titillinn er skammstafaður L. Átt er við fyrstu útgáfu bókanna: Af jörðu ertu kominn: I. Eldur, Akureyri: Porsteinn M. Jónsson, 1941 og Landið handan landsins, Akureyri: Porsteinn M. Jónsson, 1944.

11 Sjá t.a.m. Guðmundur Daníelsson, „Eftirmáli 2. útgáfu“, Sandur, Ritsafn Guðmundar Daníelssonar, Reykjavík: Ísafoldarprentsmiðja, 1967, bls. 204209, hér bls. 208; Guðmundur G. Hagalín, „Skáldið William Faulkner“, Lesbók Morgunblaðsins, 14. janúar 1951, bls. 20-22; Helgi Sæmundsson, „FAULKNER LÁTINN“, Alpýðublaðið, 19. júlí 1962, bls. 4. 
hjálmsson og Guðbergur Bergsson gengist við áhrifum frá honum pá hefur íslensk bókmenntaumræða að langmestu leyti farið varhluta af peim viðamiklu rannsóknum sem gerðar hafa verið á Faulkner og verkum hans og stundum er vísað til sem hins alpjóðlega Faulkner iðnaðar. ${ }^{12}$

Í pessari grein er horft á rannsóknir undanfarinna tveggja áratuga á pví hvers vegna verk Faulkners hafa höfðað sérstaklega til rithöfunda á svæðum sem staðið hafa höllum fæti í efnahagslegu og menningarlegu tilliti, ýmist innan heimalanda sinna eða gagnvart erlendu valdi. Meðal pess sem fræðimenn hafa lagt sérstaka rækt við er að kanna tengsl milli forms skáldverka Faulkners og pess sögu- og félagslega jarðvegs sem pau spruttu úr. ${ }^{13} \mathrm{Um}$ fjöllunin hér á eftir skiptist í tvo hluta; í peim fyrri verður kannað með hvaða hætti Guðmundur Daníelsson nýtir byggingarlag og hugmyndaheim skáldsögunnar Light in August eða Ljós i ágúst í Eldi, fyrsta bindi príleiksins Af jörðu ertu kominn..$^{14}$ Í peim síðari er spurt hvort og pá hvernig Guðmundur

12 Jay Parini, „Faulkner's Lives“, A Companion to William Faulkner, ritstj. Richard C. Moreland, Maldan, Oxford og Victoria: Blackwell Publishing, 2007, bls. 104-112, hér bls. 105. Auk fjölda ævisagna, fræðirita og ritgerðasafna sem komið hafa út má nefna að The University of Mississippi hefur í á fimmta áratug staðið fyrir árlegum pematengdum ráðstefnum undir yfirskriftinni Faulkner and Yoknapatawpha Conference sem síðan er fylgt eftir með veglegum ráðstefnuritum. Einnig eru starfrækt rannsóknarnet víða um heim en öflugast peirra er The Faulkner Society, sem gefur út tímaritið The Faulkner Journal tvisvar á ári auk pess að skipuleggja málstofur á helstu hugvísindapingum Bandaríkjanna, m.a. árlegri ráðstefnu Modern Language Association. Margar rannsóknir liggja fyrir á viðtökum Faulkners og verka hans í einstökum pjóðlöndum par sem einkum er horft á pýðingar og blaðadóma, auk peirra rannsókna sem pegar hafa verið nefndar neðanmáls má nefna Gordon Price-Stephens, „The British Reception of William Faulkner 1929-1962“, Mississippi Quarterly 18: 3/1965, bls. 119-200 og François Pitavy, „The Making of a French Faulkner: A Reflection on Translation“, The Faulkner Fournal 24: 1/2008, bls. 83-97.

13 Hosam Aboul-Ela birtir yfirlit yfir pessar rannsóknir í greininni „Faulkner as/and the postcolonial writer", William Faulkner in Context, ritstj. John T. Matthews, New York: Cambridge University Press, 2015, bls. 288-97.

14 Ljós í ágúst kom upphaflega út í Bandaríkjunum í október árið 1932 undir heitinu Light in August. I meginmáli ritgerðarinnar er vísað til skáldsögunnar Ljós í ágúst en svo hefur hún verið kölluð á íslensku a.m.k. síðan 1953 pegar kaflinn á „Krossgötum“ birtist í tímaritinu Úrvali 12. árg. 6. hefti bls. 89-112. Pýðandi kaflans er Óskar Bergsson. Árið 1999 gaf bókaforlagið Bjartur Ljós i ágúst út í heild sinni í íslenskri býðingu Rúnars Helga Vignissonar. Í meginmáli greinarinnar er peirri hefð í Faulkner-fræðum fylgt að vísa til útgáfu The Library of America. Er heiti Light in August skammstafað LA í tilvísunum í meginmáli en á eftir fylgir blaðsíðutal. Um er að ræða: William Faulkner, Light in August, William Faulkner: Novels 1930-1935, New York: The Library of America, 1985, bls. 399-774. 
Daníelsson nýti skáldsagnaformið til að fjalla um Ísland sem hjálendu eða nýlendu Dana á tímum pegar tekið er að hilla undir sjálfstæði pjóðarinnar. Fjallað verður um skáldsöguna í samhengi eftirlendufræða og lögð sérstök áhersla á að greina pá mynd sem hún birtir af bæði valdsmönnum og peim sem standa höllum fæti í íslensku samfélagi. Einnig verður kannað hvernig persónur skáldsögunnar notast við staðalmyndir af framandi landsvæðum og íbúum peirra til að grundvalla sjálfsmynd sína. Að lokum verða tvö dæmi úr Eldi annars vegar og Landinu handan landsins hins vegar skoðuð og greind en par eru persónur beittar kynferðislegu ofbeldi um leið og jaðarstaða peirra er undirstrikuð með tilvísun til framandi útlitseinkenna og fötlunar.

\section{Faulkner og jaðarinn}

Í bók sinni La République mondiale des lettres frá árinu 1999 bendir Pascale Casanova á að í miðjum heimsbókmenntakerfisins, og pá einkum og sér í lagi París, hafi Faulkner verið hampað fyrir tæknilegar nýjungar á sviði skáldsagnagerðar en pær aðeins metnar á forsendum forms og stílbragða. ${ }^{15}$ Á jöðrum bókmenntaheimsins hafi aftur á móti verið litið á pessar nýjungar sem tæki í baráttu fyrir frelsi. Verk Faulkners hafi skipað sérstakan sess meðal höfunda um víða veröld sem vildu brjótast undan yfirvöldum sem drottnuðu yfir pví bókmenntakerfi sem peir lifðu og hrærðust í. Faulkner hafi fundið farveg fyrir reynslu af pólitískri, fagurfræðilegri og bókmenntalegri sjálfheldu. Hann hafi gert höfundum í fátækum heimshlutum kleift að fella mótsagnakenndustu pætti tilveru sinnar í viðurkennt bókmenntaform. Í kafla sem helgaður er Faulkner fjallar Casanova um höfunda frá mismunandi tímaskeiðum, land- og menningarsvæðum sem eiga pað sameiginlegt að hafa fundið til andlegs skyldleika (e. affinity) við Faulkner. Hún kýs að nota petta orðalag til að losna við að tala um áhrif (e. influence) sem henni finnst gefa til kynna að annar aðilinn sé aðeins óvirkur móttakandi. Hún fjallar m.a. um Juan Benet sem hóf að umbylta formi skáldsögunnar á Spáni á sjöunda áratugnum, hinn alsírska Rachid Boudjedra sem gerði ápekkar tilraunir á arabísku á níunda áratugnum og loks beinir hún sjónum að Gabriel García Márques, Mario Vargas Llosa og öðrum höfundum Rómönsku Ameríku sem slógu í gegn á sjöunda og áttunda áratugnum. ${ }^{16}$

Casanova leggur áherslu á að allir pessir höfundar fjalli um frumstætt sveitalíf í skáldsögum sínum en kynni peirra af verkum Faulkners hafi gert

15 Sjá, Pascale Casanova, The World Republic of Letters, bls. 336-37.

16 Sama heimild, bls. 339. 
peim kleift að setja hefðbundin viðfangsefni í nútímalegan búning. ${ }^{17}$ Peir hafi enn fremur leitað innblásturs í erlendum bókmenntum og rætt opinskátt um pau áhrif sem Faulkner hafði á pá til að sýna fram á sérstöðu sína í bókmenntum heimalanda sinna.

Staðfærsla Guðmundar Daníelssonar á hugmyndum og aðstæðum úr verkum Faulkners, sem hann aðlagar að íslensku sveitasamfélagi og veruleika í nýstárlegu formi, kann að vera pess valdandi að príleikurinn fellur ekki að hefðbundnum hugmyndum um próun íslenskra lausamálsbókmennta. Pegar Kristinn E. Andrésson fjallar um Af jörðu ertu kominn í bókmenntasögu sinni, Islenzkar nútímabókmenntir 1918-1948, leggur hann áherslu á pað hversu sundurleitt verkið sé og erfitt að sjá á pví listrænt form. ${ }^{18}$ Lokadómur hans er sá að Guðmund vanti meiri kunnáttu í skáldsagnagerð en um leið er sem deilt sé á móderníska fagurfræði í skáldskap undir rós. Skýrasta dæmið um petta eru eftirfarandi orð Kristins: „Oft er á pað bent, hvernig listin deyr hjá skáldunum, er pau tilbiðja hana sjálfrar hennar vegna. En í rauninni fer á sömu leið fyrir peim skáldum, sem gera „lífið,“ p.e. stefnuleysið og formleysið að hugsjón sinni, að verk peirra verða ekki list. “19 Pegar príleikurinn var endurútgefinn á sjöunda áratugnum taldi bókmenntagagnrýnandinn Ólafur Jónsson petta vera „metnaðargjarnasta skáldverk“ Guðmundar en samt sem áður virðist hann ekki hafa haft afgerandi áhrif á stöðu hans í íslenskum bókmenntum. ${ }^{20} \mathrm{Um}$ príleikinn er t.a.m. ekki fjallað í $I$ lenskri bókmenntasögu Máls og menningar endapótt mörg önnur verka hans beri par á góma. ${ }^{21}$ Guðmundur Daníelsson minnti reglulega á kynni sín af

17 Sama heimild, bls. 345.

18 Kristinn E. Andrésson, Íslenzkar nútímabókmenntir 1918-1948, Reykjavík: Mál og menning, 1949, bls. 371 .

19 Sama heimild, bls. 375 .

20 Í ítarlegum blaðadómi sem Ólafur Jónsson skrifar í tilefni af endurútgáfu príleiksins lýsir hann peim vanda sem kynslóð Guðmundar stóð frammi fyrir, kemur hún heim og saman við pá pætti sem Casanova greindi hjá peim höfundum sem hún taldi sækja til Faulkners. Vandann segir Ólafur hafa verið pann að „viðhalda epískri og raunsæislegri sagnahefð á tímum gagngerðra samfélagsbreytinga, umbrota og próunar sem ögraði og vefengdi viðtekna skáldskaparháttu, endurnýja lífræna hefðá tíma sem bauð peim úrkynjun staðnaðra forma“. Sjá, Ólafur Jónsson, „Af jörðu ertu kominn“, Vísir 6. nóvember 1970, bls. 7.

21 Jón Yngvi Jóhannsson fjallar um Guðmund Daníelsson í tengslum við íslensku sveitasöguna í Íslenskri bókmenntasögu IV og telur hann til „minni spámanna“ (258). Umfjöllun hans um skáldsöguna Gegnum lystigarðinn frá árinu 1938 er einkar forvitnileg. Segir hann söguna sýna ákveðna meðvitund um sveitasagnahefðina og vera sögu um sögu á öðrum præði (263). Petta sama einkennir síðasta bindi 
skáldverkum Faulkners meðan honum entist aldur til. ${ }^{22}$ Trúlega vegna pess að hann gerði sér grein fyrir pví að hann var meðal fyrstu skáldsagnahöfunda Evrópu til að tileinka sér frásagnartækni Faulkners og byggja á henni við sköpun eigin skáldverks.

Sama ár og bók Casanova kom út, á frummálinu frönsku, sendi Deborah Cohn frá sér bókina History and Memory in the Two Souths. Par er líka fjallað um pýðingu Faulkners fyrir höfunda Rómönsku Ameríku og lögð áhersla á að tengsl séu á milli forms skáldverkanna og pess félagslega veruleika sem pau endurspegla. ${ }^{23}$ Hún lýsir peim margháttuðu áhrifum sem ósigur Suðurríkjanna í bandaríska borgarastríðinu hafði a sjálfsmynd og sálarlíf íbúanna, efnahag svæðisins og pólitíska stöðu pess innan Bandaríkjanna. Pegar höfundar Rómönsku Ameríku komust í kynni við verk Faulkners á fjórða áratugnum fangaði hann ímyndunarafl peirra vegna pess að peir upplifðu aðstæður í Suðurríkjunum sem hliðstæður við klafa nýlendutímans. Pegar Cohn beinir sjónum að höfundum Rómönsku Ameríku hafnar hún pví að um einhliða áhrif Faulkners sé að ræða, rétt eins og Casanova, og leggur pess í stað til að litið sé á Suðurríkin og Rómönsku Ameríku sem landssvæði eða rými með ápekka eiginleika. ${ }^{24}$ Sá fræðilegi rammi sem Cohn skilgreindi í bókinni er einnig lagður til grundvallar í ritgerðarsafninu Look Away: The U.S. South in New World Studies, sem hún ritstýrði ásamt Jon Smith árið 2005. Par má finna sérstakan kafla um Faulkner með ritgerðum eftir sex ólíka fræðimenn sem nýta m.a. kenningar nýlendu- og eftirlendufræða. ${ }^{25}$

Eins og Cohn staðsetur Hosam Aboul-Ela sínar rannsóknir innan kenn-

príleiksins Landið handan landsins og hefði verið forvitnilegt að sjá Jón Yngva gera nánari grein fyrir pessu einkenni á skáldsap Guðmundar. Sjá, Jón Yngvi Jóhannsson, „Lausamálsbókmenntir á fjórða áratugnum“, Íslensk bókmenntasaga, ritstj. Guðmundur Andri Thorsson, Reykjavík: Mál og menning, 2006, bls. 224304. Tímabilaskipting Íslenskrar bókmenntasögu IV kann að ráða pví að príleikurinn lendir milli skips og bryggju pví umfjöllun um lausamálsbókmenntir er haldið áfram í kafla sem nefnist „Árin eftir seinna stríð“. Par fjallar Dagný Kristjánsdóttir m.a. um sögulegar skáldsögur Guðmundar frá sjötta og sjöunda áratugnum. Sjá, Dagný Kristjánsdóttir, „Árin eftir seinna stríð“, Íslensk bókmenntasaga IV, bls. 419-661, hér bls. 501-502 og 507-508.

22 Guðmundur Daníelsson, „Guðmundur Gíslason Hagalín“, Sérhefti: Guðmundur Gíslason Hagalín, Morgunblaðið 9. mars 1985, bls. B2.

23 Deborah N. Cohn, History and Memory in the Two Souths: Recent Southern and Spanish American Fiction, Nashville and London: Vanderbilt University Press, 1999, bls. 1-2.

24 Sama heimild, bls. 4-7.

25 Look Away: The U.S. South in New World Studies, Durham og London: Duke University Press, 2004. 
ingaramma nýlendu- og eftirlendufræða í umfjöllun sinni um verk Faulkners í bókinni Other South: Faulkner, Coloniality, and the Mariátegui Tradition (2007). Aboul-Ela fer pá leið að greina tengslin milli nýlendu hagkerfa og menningarframleiðslu. Hann staðhæfir að Suðurríkin hafi verið eitt af fyrstu svæðunum sem hafi lotið efnahagslegu forræði (e. hegemony) Bandaríkjanna og að í kjölfar seinni heimsstyrjaldarinnar hafi bandarísk stjórnvöld lagt undir sig fjölmörg lönd með sömu aðferðafræði að vopni, p.e.a.s. fjárfestingum og beinum og óbeinum afskiptum af stjórnmálum. ${ }^{26}$ Petta er að hans mati ný tegund af nýlendustefnu sem byggðist ekki á landnámi herrapjóðarinnar heldur á að nýlendunum sé stjórnað úr fjarska með valdi sem sé oft og tíðum erfitt að festa hendur á. ${ }^{27}$ Hugtakið forræði er sótt til ítalska marxistans Antonios Gramscis en pað lýsir pólitísku yfirvaldi sem byggir á sampykki peirra undirokuðu, sampykki sem er tryggt með útbreiðslu og alpýðuhylli peirrar heimsmyndar sem valdastéttin teiknar upp. ${ }^{28}$ Hosam Aboul-Ela vinnur áfram með kenningar Gramscis í greininni „Faulkner as/ and the Postcolonial Writer" en par leggur hann áherslu á að pær víkki út umræðu um verk Faulkners í samhengi eftirlendufræða. Í fyrsta lagi geri pað hugmyndina um Suðrið huglæga, p.e.a.s. svæðið sé ekki lengur skilgreint landfræðilega heldur út frá hugmyndum um menningarlegt og pólitískt forræði. Í öðru lagi segir Aboul-Ela pessa endurskilgreiningu vekja upp spurningar um pað hvers vegna ekki hafi farið fram viðameiri rannsóknir á tengslunum milli Faulkners og peirra fjölmörgu rithöfunda sem fengist hafa við endurritun verka hans í peim nýlendum sem finna má utan Suður- og Norður-Ameríku. ${ }^{29}$

Í pessari grein er ætlunin að taka áskorun Aboul-Ela og skoða með hvaða hætti fortíð Íslands sem nýlendu er endurrituð í fyrsta bindi Af jörðu ertu kominn. Fyrst parf pó að glöggva sig á pví hvað við er átt pegar talað er um Ísland sem nýlendu. ${ }^{30}$ Frumkvöðlar eftirlendufræðanna komu flestir frá fyrr-

26 Hosam Aboul-Ela, Other South: Faulkner, Coloniality, and the Mariategui Tradition, Pittsburgh: University of Pittsburgh Press, 2007, bls. 9-10.

27 Sama heimild, bls. 15.

28 Hugtakið forræði var fyrirferðarmikið í skrifum Gramscis meðan hann sat í haldi ítölsku fasistastjórnarinnar frá árinu 1926 og par til hann dó árið 1935. Hugtakið hefur gengið í endurnýjun lífdaga undanfarna áratugi og verið nýtt til að greina vald af margvíslegum toga. Sjá, Thomas R. Bates, "Gramsci and the Theory of Hegemony“, Journal of the History of Ideas 36: 2/1975, bls. 351-366, hér bls. 352.

29 Hosam Aboul-Ela, „Faulkner as/and the postcolonial writer“, bls. 295.

30 Sögu eftirlendufræða má rekja aftur til fyrri hluta tuttugusta aldar en hún hefur verið tengd rannsóknum fræðimanna sem beindu sjónum að sjálfsmynd nýlendubúa 
um nýlendum evrópskra nýlenduvelda í Asíu, Afríku og Rómönsku Ameríku; frá Evrópu séð var pví horft austur og suður á bóginn. Pegar fræðimenn tóku að beina sjónum í norður komust peir brátt að raun um að vandamál nýlendustefnunnar í suðri og austri voru af öðrum toga en á norðurslóðum. Norðurslóðir tilheyrðu ekki annarri heimsálfu heldur var um að ræða tiltölulega lítið landsvæði par sem íbúarnir voru í flestum tilvikum „eins“ og pví komu flokkunarkerfi kynpáttahyggju og trúarbragða aðeins að gagni að takmörkuðu leyti. Á undanförnum tveimur áratugum eða svo hafa fræðimenn á sviði hug- og félagsvísinda skoðað Ísland út frá sjónarhorni eftirlendufræða í vaxandi mæli. Hefur pessi nálgun ekki verið óumdeild og varðar pað m.a. notkun nýlenduhugtaksins til að lýsa stöðu Íslands innan danska ríkisins. ${ }^{31}$ Í pólitískum skilningi virðist ekki vera hægt að gefa afdráttarlaust svar um pað hvort Ísland hafi verið nýlenda eða ekki en hins vegar hefur verið bent á

og börðust um leið fyrir pólitísku og menningarlegu sjálfstæði frá nýlenduveldum Evrópu. Sá rammi, sem fræðunum er oftast settur í dag, er talinn hafa verið skilgreindur í bók Edwards Saids Orientalism sem kom út árið 1978. Innan hans er lögð áhersla á pá spennu og krafta sem eru til milli miðborgar nýlenduveldisins (e. metropolis) og fyrrum nýlendna; horft er gagnrýnum augum á Evrópu-miðaðan hugsunarhátt (e. Eurocentrism) og sérstök rækt lögð við pá hópa sem telja má fórnarlömb hans vegna t.d. litarháttar, hernaðarlegrar útpenslustefnu, arðráns eða misnotkunar af ýmsu tagi. Sjá, Hans Bertens, Literary Theory, priðja útgáfa, The Basics, London og New York: Routledge, 2014, bls. 169-173.

31 Gavin Lucas og Angelos Parigoris, „Icelandic Archaeology and the Ambiguities of Colonialism", Scandinavian Colonialism and the Rise of Modernity: Small Time Agents in a Global Arena, ritstj. Magdalena Naum ogJonas M. Nordin, Contributions to Global Historical Archaeology, New York/ Heidelberg/Dordrecht/London: Springer, 2013 bls. 89-104, hér bls. 91-94. Í pessu sambandi hefur verið bent á röksemdafærslu Jóns Sigurðssonar fyrir sjálfstæði Îslands en hún fólst í pví að landið væri hvorki nýlenda né hjálenda (d. biland) heldur sérstakt sambandsland í persónulegu sambandi við konung Noregs og síðar Danmerkur. Guðmundur Hálfdanarson, „Var Ísland nýlenda“, Saga 52: 1/2014, bls. 42-75, hér bls. 47. Prátt fyrir andstöðu Jóns festi hugtakið hjálenda sig í sessi pegar kom að pví að lýsa stöðu Íslands innan danska ríkisins, virðist pað hafa hugnast Íslendingum betur en nýlenda pví pað aðgreindi landið frá nýlendum Dana, eins og Færeyjum, Grænlandi og Dönsku Vestur Indíum, en færði pað um leið nær vestrænum Evrópupjóðum sem peir vildu samsama sig. Sjá, Íris Ellenberger, „Somewhere Between "Self" and "Other": Colonialism in Icelandic Historical Research", Nordic Perspectives on Encountering Foreignness, ritstj. Anne Folke Henningsen, Leila Koivunen og Taina Syrjämaa, Histories 1, Turku: General History, University of Turku, 2009, bls. 99-114, hér bls. 100. Tregða Íslendinga til að láta flokka sig með íbúum nýlendna Dana kemur greinilega fram í viðbrögðum peirra við Nýlendusýningunni í Kaupmannahöfn árið 1905, sjá Jón Yngvi Jóhannsson, „Af reiðum Íslendingum: Deilur um Nýlendusýninguna 1905“, Pjóðerni i púsund ár, ritstj. Jón Yngvi Jóhannsson, Kolbeinn Óttarsson Proppé og Sverrir Jakobsson, Reykjavík: Háskólaútgáfan, 2003, bls. 135-150. 
að í efnahagslegum og menningarlegum skilningi beri Ísland mörg einkenni nýlendu. ${ }^{32}$ Á öðrum áratugi 21. aldar hefur skapast hefð innan fræðanna fyrir pví að fjalla um norðurslóðir út frá sjónarhorni eftirlendufræða og er Ísland hluti af peirri umræðu ásamt Færeyjum og Grænlandi. ${ }^{33}$ Pó spurningunni um pað hvort Ísland hafi verið nýlenda eða ekki sé oft velt upp í pessu sambandi pá má segja að ákveðin sátt sé um að á milli Íslands og Danmerkur hafi verið valdaójafnvægi og hallað hafi á Íslendinga í pólitísku, menningarlegu og efnahagslegu tilliti og að petta ójafnvægi hafi mótað sjálfsmynd beggja pjóða í samskiptum pegna peirra. ${ }^{34}$

\section{II}

\section{Eldur og Ljós i ágúst}

Af jörðu ertu kominn gerist í tveimur sveitum sem aðskildar eru af öræfum, óbrúuðu fljóti, opnum gjám, eyðimörk og jökli. Austan við jökulinn er Neshreppur sem er aðalsögusvið Elds en vestan við hann er Hraunamanna-

32 Guðmundur Hálfdanarson, „Var Ísland nýlenda“, bls. 70. Íris Ellenberger, „Somewhere Between "Self" and "Other": Colonialism in Icelandic Historical Research“, bls. 104-106. Mannfræðingarnir Kristín Loftsdóttir og Gísli Pálsson sem bæði hafa tekið virkan pátt í að móta sjónarhorn nýlendufræða pegar Ísland er annars vegar taka afdráttarlaust til orða um stöðu Íslands í bókarkafla árið 2013. Hann hefst einfaldlega á orðunum: „Sem nýlenda Dana og Norðmanna á tímabilinu 1262 til 1944, var staða Íslands gjarna sérstök í menningarlegu og geopólitísku tilliti.“ Sjá, Kristín Loftsdóttir og Gísli Pálsson, „Black on White: Danish Colonialism, Iceland and the Caribbean", Scandinavian Colonialism and the Rise of Modernity, ritstj. Magdalena Naum og Jonas M. Nordin, New York/ Heidelberg/Dordrecht/ London: Springer, 2013, bls. 37-52, hér bls. 37.

33 Sjá, t.a.m. ritgerðasöfnin: Scandinavian Colonialism and the Rise of Modernity: Small Time Agents in a Global Arena, ritstj. Jr. Charles E. Orser, Contributions To Global Historical Archaeology, New York/Heidelberg/Dordrecht/London: Springer, 2013; The Postcolonial North Atlantic, vol. 20, Berliner Beiträge zur Skandinavistik, Berlin: Noreuropa-Institut der Humboldt-Universität, 2014; Postcolonial Perspectives on the European High North: Unscrambling the Arctic, London: Palgrave Macmillan, 2016.

34 Sumarliði Ísleifsson kemst að peirri niðurstöðu í doktorsritgerð sinni að Ísland hafi ekki verið nýlenda og líta beri á pað sem „fjarlægt jaðarsvæði í danska ríkinu“ pað breytir pví hins vegar ekki að hann leggur til að nýta megi „fræðilega umræðu um nýlendustefnu pó að tiltekið land hafi ekki formlega verið nýlenda heldur jaðarsvæði innan stærra ríkis eða jafnvel verið sjálfstætt ríki, a.m.k. að forminu til“. Sjá, Sumarliði R. Ísleifsson, Tver eyjar á jaðrinum: Ímyndir Íslands og Grenlands frá miðöldum til miðrar 19. aldar, Reykjavík: Háskólaútgáfan; Sagnfræðistofnun Háskóla Íslands, 2015, bls. 31-32. 
hreppur par sem síðari bindin, Sandur og Landið handan landsins, eiga sér stað. Eldur og Sandur gerast samtímis að mestu leyti eftir aldamótin nítjánhundruð. ${ }^{35}$ Præðir peirra eru raktir hlið við hlið en skerast í einum lykilatburði sem tengist jarðarkaupum. Í eftirmála annarrar útgáfu að Sandi lýsti Guðmundur Daníelsson aðferð sinni svo að reynt sé „að varpa ljósi á söguefnið úr tveim gagnstæðum áttum, líkt og maður ætlaði að ljósmynda hús og umhverfi pess, fyrst framhliðina, síðan bakhliðina“." Eldur og Sandur gerast báđar á tveimur tímaplönum en í Landinu bandan landsins hafa sögur fortiððarinnar verið leiddar til lykta og par er tímaplanið fyrst og fremst eitt. Í umræddum eftirmála segir Guðmundur að í niðurlagi Sands „renni sögurnar saman í eitt“. Og hann bætir við: „Ég sneið [byggingarlag sögunnar] eftir algengu fyrirbrigði í íslenzkri náttúru: par sem tvö straumvötn renna saman og falla síðan í einum farvegi til sævar, svo sem: Sogið, Hvítá og Ölfussá.“

Í lýsingu Guðmundar Daníelssonar á byggingu príleiksins koma fram minnst prjú atriði sem tengja má fagurfræði Faulkners. Í fyrsta lagi er pað áhersla á sagnaheiminn og landfræði hans sem á sér hliðstæðu í Yoknapatawpha-sýslu Faulkners en hún er sögusvið flestra skáldsagna hans. Hún er ímyndað landssvæði en um leið hliðstætt heimahögum hans sjálfs í Mississippi. Í öðru lagi er gengið út frá pví sem vísu að atburðir, eins og hlutir, eigi sér fleiri en eina hlið. Í priðja og síðasta lagi verður tíminn og framvinda hans að sérstöku afli innan sagnaheimsins, tímanum vindur ekki einatt fram heldur eru ólíkir sögupræðir raktir að einum punkti par sem peir koma saman. Pessi prjú atriði hafa afgerandi áhrif á pað hvernig sögumaður verkanna er uppbyggður. Ef horft er sérstaklega á Af jörðu ertu kominn með hliðsjón af Ljósi i ágúst pá eru sögurnar sagðar af alvitrum priðju persónu sögumönnum. Peir kynna til leiks mikinn fjölda persóna sem sumar hverjar eru vitundarmiðjur verkanna í skemmri eða lengri tíma. Sögumennirnir flakka frjálslega fram og aftur í tíma og eru færir um að lýsa viðbrögðum og sjónarmiðum fólks, rétt eins og peir séu sagnaandar sem fara um og fylgjast með öllu sem gerist í sveitunum. Sögurnar eru pannig settar saman af ólíkum sjónarhornum sem stefnt er saman og lesandanum er oft og tíðum látið eftir að fella dóma um pað sem honum er leitt fyrir sjónir. Pegar horft er til einstakra hluta príleiksins eru líkindin með Eldi og Ljósi i ágúst mest sláandi. Skýrast koma pau fram í umfjöllun um leyndarmál sem tengjast faðerni aðalpersónanna og pau víðtæku áhrif sem pað hefur í för með sér.

35 „Hin nýja bók Guðmundar Daníelssonar: Af jörðu ertu kominn“, Albýðublaðið, 5. september 1941.

36 Guðmundur Daníelsson, „Eftirmáli 2. útgáfu“, bls. 208. 


\section{Tveir bastarðar}

Í Suðurríkjum Bandaríkjanna eru kynpáttafordómar rótgrónir. Á tímabilinu 1882-1927 voru t.a.m. 3.513 svartir karlmenn fórnarlömb múgmorða (e. lynching) og 76 konur. ${ }^{37}$ Múgmorðin beindust að karlmönnum vegna pess að kynhvöt peirra átti að vera stjórnlaus, sérstaklega pegar hvítar konur voru annars vegar. Ef grunur lék á að kynferðisbrot hefði verið framið var pað ekki skoðað sem einangrað fyrirbæri heldur yfirfært á samfélagið í heild og fórnarlambið var tákngert fyrir pá ógn sem steðjaði að menningu hvítra. ${ }^{38}$ Litarhaft var óvéfengjanleg sönnun um óæðri uppruna en fleiri atriði gátu gefið vísbendingu um að einstaklingur hefði svart blóð í æðum. Slíkar vísbendingar hafa verið nefndar kynpáttamörk (e. racial marker) og gátu t.d. falist í hári, húð, augum, tali, klæðaburði eða hegðun. ${ }^{39}$ Í hverju og einu samfélagi geta kynpáttamörkin verið ólík; í sumum tilvikum tengjast pau jákvæðum páttum en í öðrum neikvæðum. En pau eru notuð til að flokka og aðgreina pá æðri frá hinum óæðri.

Í skáldsögu Faulkners Ljosi i ágúst er óljós uppruni hins dularfulla Joes Christmas í brennidepli. Christmas er hvítur á hörund en samfélagið tengir ýmislegt í háttalagi hans og líkamsgerð við svarta. Af pessum sökum fara hviksögur um uppruna hans á kreik hvar sem hann kemur. Christmas bregst við með pví að sveipa líf sitt dulúð. Hann bruggar m.a. á laun og á í leynilegu ástarsambandi við ógifta konu, Joanna Burden. Hún lifir á jaðri samfélagsins í Jefferson vegna pess að fjölskylda hennar kom frá Norðurríkjunum á tímum enduruppbyggingarinnar eftir borgarastríðið og studdi afnám prælahalds. Samband peirra kemst upp eftir að Joanna finnst skorin á háls í brennandi húsi sínu sem leiðir til pess að Christmas er geldur og tekinn af lífi án dóms og laga. Prátt fyrir hrikaleik glæpsins, sem hann er sakaður um, er aftakan fyrst og fremst afleiðing af meintu litarhafti hans. Eldsvoðinn á heimili Burdens er pungamiðja atburðarásarinnar pví reykjarsúlan sem teygir sig upp til himins sést víða að og verður að skurðpunkti ólíkra frásagna. Á sama tíma vekur hún upp spurningar um hvað brenni, orsakir pess og möguleg fórnarlömb (LA 437). Með pessum hætti magnast upp spenna og smám saman leiðir sagan lesandann að eldsupptökunum frá sjónarhorni ólíkra

37 Adam Gussow, Seems like Murder Here: Southern Violence and the Blues Tradition, Chicago: The University of Chicago Press, 2002, bls. 18.

38 Deborah Barker, „Moonshine and Magnolias: The Story of Temple Drake and the Birth of a Nation“, The Faulkner Fournal 22: 1-2/2006, bls. 140-65, hér bls. 142.

39 Werner Sollors, Neither Black nor White yet Both: Thematic Explorations of Interracial Literature, New York/Oxford: Oxford University Press, 1997, bls. 151. 
persóna. Frásögnin er oft og tíðum rofin með endurlitum og útúrdúrum en lengst slíkra er frásögn af erfiðum uppvexti Christmas. Рað kemur upp úr kafinu að afi hans, Eupheus „Doc“ Hines, hafði ráðið föður hans bana vegna pess að hann var pess fullviss að um æðar hans rynni negrablóð (LA 676). Af sömu ástæðum horfði afinn upp á dóttur sína deyja af barnsförum pegar Christmas kom í heiminn án pess að aðhafast nokkuð til að bjarga henni (LA 679). Afinn kemur drengnum í framhaldinu fyrir á munaðarleysingjahæli en vill samt sem áður hafa auga með honum og gerist húsvörður á munaðarleysingjahælinu. Hið vökula augnaráð afans gerir drenginn meðvitaðan um sjálfan sig og beinir að honum athygli hinna barnanna sem taka að uppnefna hann negra (LA 682). Pegar ljóst er að orðrómurinn muni spyrjast út meðal fullorðna fólksins óttast Hines að drengurinn verði fluttur á munaðarleysingjahæli fyrir blökkubörn og pá grípur hann til pess ráðs að ræna honum í skjóli nætur. Christmas er settur í fóstur hjá strangtrúuðu fólki en afinn hverfur úr lífi hans um allnokkurt skeið. Fósturvistin reynist drengnum erfið enda er hann beittur miklu harðræði. Afinn skýtur svo ekki aftur upp kollinum fyrr en Christmas hefur verið handsamaður í nágrannabænum Mottstown fyrir morðið á Joanna Burden. Pá gerir Hines hróp að Christmas og hvetur til pess að hann sé tekinn af lífi án dóms og laga vegna pess að hann sé negri.

Faðernismálið í Eldi, snýst ekki um svart blóð heldur danskt og tengist útgerðarmanninum Sögaard Nielsen sem barnar mállausa vinnukonu sína Guðrúnu. Að undirlagi héraðshöfðingjans Jóhannesar hreppstjóra í Breiðavík heldur hann faðerninu leyndu og með klækjum er rauðhært manntröll, Runólfur Sveinsson, sem gengur undir nafninu Runki, fenginn til að giftast henni gegn pví að hann fái bæinn Gröf til eignar og sakaruppgjöf fyrir ýmsa smáglæpi (E 68). Um leið og gengið hefur verið frá ráðahagnum nauðgar Runólfur Guðrúnu (E 72-73) en hún á síðar eftir að deyja af barnsförum pegar drengurinn Gísli kemur í heiminn. Um Guðrúnu er fjallað í sérstökum kafla undir lok greinarinnar en dveljum um sinn við leyndarmálið um faðerni Gísla í Gröf. Faðernismálið er í fyrstu harmleikur einstaklinga en færist yfir á svið samfélagsins alls pegar danski kaupmaðurinn lifir skilgetna afkomendur sína sem verður til pess að eignir hans erfast til fjarskyldra ættingja hans. Útgerðina og framleiðslutækin, sem henni fylgja, tekur fjölskyldan til sín og flytur annað. Petta leggst sérstaklega pungt á Jóhannes sem hafði lagt á ráðin um að systir sín giftist syni Nielsens. Frá öllu pessu er greint í löngu endurliti og með sama hætti er sögð sagan af erfiðum uppvexti Gísla. Á petta sér skýra samsvörun í Ljósi i ágúst, bæði í frásagnarað- 
ferð og persónusköpun, en Gísli og Joe Christmas eru augljósar hliðstæður. Jóhannes er hins vegar í stöðu Eupheus „Doc“ Hines pví hann fylgist með uppvexti Gísla, plagaður af leyndarmálinu sem hann varðveitir og leitar sífellt meira á huga hans eftir pví sem hann eldist. Og líkt og Joe Christmas finnur drengurinn Gísli fyrir augunum sem hvíla á honum (E 116).

Í Ljósi i ágúst og Eldi vekja uppeldissögur Joes Christmas og Gísla í Gröf samúð með persónum sem eru ógeðfelldar við fyrstu sýn. Hin raunverulegu illmenni eru hins vegar mennirnir sem kalla yfir bá samfélagslega bölvun vegna uppruna peirra og eins peir sem beita pá harðræði í uppvextinum. Á sögunum tveimur er pó grundvallarmunur bví í Ljósi i ágúst setur grunurinn um að svart blóð renni um æðar Joes Christmas hann í undirskipaða stöðu. Hann missir forréttindastöðu hvíts manns og færist út á jaðar samfélagsins. Í Eldi vill höfðinginn Jóhannes aftur á móti halda faðerni bastarðsins leyndu, ekki vegna pess að pví fylgi skömm að Nielsen sé útlenskur, heldur vill Jóhannes tryggja völd sín í samfélaginu sem byggja á óbreyttu ástandi. Hann vill pannig koma í veg fyrir að eignir Danans erfist til afkomanda konu af lágum stigum, vinnukonu, sem er í hans augum ,aumingi að vissu leyti“ (E 60). Jóhannes orðar pá jaðarstöðu sem hann setur Gísla í með ýmsum hætti, nefnir hann m.a. konungsson „í álögum“ sem hafi verið „borinn út, áður en hann fæddist“ (E 174), hann segir líka að Gísli lifi „útilegumannalífi“ (E 177) og að hann sé í „ófreskjuham“ (E 178). Rétt eins og í ævintýrunum sem myndmálið vísar til býr maður undir hamnum og göfugur uppruninn dylst engum pegar álögunum hefur verið aflétt (E 234). Í peirri heimsmynd sem Jóhannes aðhyllist eru Danir í forræðisstöðu og í honum blundar djúp prá eftir pví að samlagast Nielsen en um leið greina sig frá löndum sínum.

Annar mikilvægur páttur í byggingu Ljóss i ágúst er hvernig sjálfstæðar frásagnir tengjast saman og mynda samhljóm; hefur í pessu sambandi verið talað um kontrapunkt. ${ }^{40}$ Sjálfur lýsti Faulkner pví hvernig harmleikurinn af Joe Christmas væri undirstrikaður með sögu af nokkurs konar andstæðu hans, prestinum Moses Hightower. Í Eldi beitir Guðmundur Daníelsson sömu aðferð. Í upphafi eru lesendur kynntir fyrir séra Gylfa Sigurðssyni. Hann býr að Nesi par sem foreldrar hans hvíla og við hlið peirra hefur hann valið sjálfum sér grafarstæði (E 22). Líf prestsins virðist fullkomlega kyrrstætt. Hann er úr tengslum við umhverfi sitt og virðist nærtækasta skýringin á pví vera veikindi unnustu hans, Solveigar, sem sofið hefur 10 ár á sjúkra-

40 Martin Kreiswirth, „Plots and Counterplots: The Structure of Light in August“, New Essays on Light in August, The American Novel, ritstj. Michael Millgate, Cambridge: Cambridge University Press, 1987, bls. 55-79, hér bls. 56. 
húsi í Reykjavík (E 24). Dag einn kemur Gísli að Nesi ásamt ekkju sem hefur gerst ráðskona hjá honum, hún á fjögur börn, prjá drengi og stúlku á fermingaraldri. Gísli ber greinilega tilfinningar til stúlkunnar sem heitir Ásdís Sölvadóttir. Pegar Gylfi sér stúlkuna kvikna líka tilfinningar innra með honum pví hún minnir hann á Solveigu (E 49). Pegar uppvaxtarsaga Gísla er rakin komast lesendur að pví að hann elskaði Solveigu líka en hún var fermingarsystir hans og hélt yfir honum hlífiskildi pegar Jónas, sonur Jóhannesar hreppstjóra, stríddi honum og niðurlægði. Gísli sér Solveigu í Ásdísi rétt eins og séra Gylfi og klæðir „Solveigu, leynda ástardrauminn sinn, í gervi hennar“ (E 146). Í bæði séra Gylfa og Gísla logar sem sé eldur, forboðin ást til stúlku sem var enn „ekki fullvaxta mær og heldur ekki barn lengur,“ eins og presturinn hugsar með sér pegar hann sér hana fyrsta sinn.

Annað sem tengir mennina saman eru grafir; annars vegar gröfin sem Gylfi ætlar sjálfum sér og hins vegar bærinn Gröf sem Gísli býr á. Pessar grafir eru tákn fyrir pað hálfa líf sem peir lifa en segja má að peir séu grafnir í fortíðinni; Gylfi með heitkonu sinni en Gísli vegna leyndarmálsins um faðerni hans. Rétt eins og í Ljósi i ágúst nær skáldsaga Guðmundar dramatískum hápunkti í eldsvoða og voðaverkum honum tengdum. Pegar vígslu nýs skólahúss er fagnað í sveitinni er haldið ball og par er helstu persónum verksins stefnt saman. Gleðin yfir nýbyggingunni er hins vegar skammvinn pví aðkomumaður kveikir í húsinu og á sama tíma nauðgar Gísli Ásdísi. Prátt fyrir petta er rándýrslegum hvötum Gísla ekki fullnægt, draugur bernskunnar „augun líkamslausu“ - taka á sig mannlega mynd Jóhannesar (E 218). Gísli fer að leita Jóhannesar og kemst að pví að hann er í eldinum. Gísli sækir Jóhannes pangað en deyr sjálfur af sárum sínum. Мeð pessu hreinsar Gísli sig í augum samfélagsins pó ekki sé ljóst hvort hann hafi í raun ætlað sér að ráða Jóhannesi bana. Eftir dauða Gísla gerir Jóhannes faðerni hans opinbert og Gísli fær stöðu píslarvotts.

Nauðgun Ásdísar er lýst með fáum orðum: „Norðan við hólinn nam hann staðar og tók hana“ (E 218). Og glæpurinn er aldrei gerður opinber. Fyrst á eftir dvelur Ásdís hjá séra Gylfa og pá sýnir hún mörg merki ofbeldisins. Pegar hún leitar ásjár hjá prestinum finnst honum t.d. að „sál hennar og líkami hrópi gegnum hið pögla handtak hennar“ (E 237). Gylfa verður líka ljóst að vakandi „fól hún með vilja pað, sem pjáði hana hið innra“ en honum tekst að raða saman sundurlausum orðum sem hún hvíslar í svefni og fá pannig mynd af pví sem gerst hafði (E 242). Smám saman verður Ásdísi ljóst að hún gengur með barn. Í sögunni er pví lýst hvernig hún fer að sýna líkamleg merki pungunarinnar en svo verður fósturlát (E 276). Par sem Gísli 
skipar nú gröfina sem Gylfi hafði ætlað sjálfum sér er ekkert sem heldur í prestinn á Nesi og að lokum er gefið fyrirheit um að Gylfi og Ásdís muni yfirgefa sögusviðið í sameiningu. Samband peirra er ekki líkamlegt heldur andlegt endapótt séra Gylfi sjái að stúlkan eigi sér tvær hliðar: „Hún hefur nunnusál, en líkaminn er skapaður til nautna. Hún ber á sér svipmót tveggja ólíkra heima, en tilheyrir hvorugum nema til hálfs“ (E 279). Hið platónska samband séra Gylfa og Ásdísar á sér hliðstæðu í sambandi Byrons Bunchs og Lenu Grove í Ljósi i ágúst en Lena er fyrsta persónan sem gengur inn á sögusviðið, ólétt eftir mann sem hafði yfirgefið hana í skjóli nætur. Byron verður nokkurs konar verndari hennar, hann elskar hana en gerist aldrei nærgöngull við hana. Pegar hún hefur eignast barn sitt undir lok sögunnar fylgja lesendur peim út af sögusviðinu en í sameiningu ætla pau að halda áfram að leita að föður barnsins.

Light in August er tvíræður titill pví skilja má orðið light bæði sem ljós og sem léttir. Tengja má fyrri merkinguna hinum fjölmörgu náttúrulýsingum sem finna má í bókinni en par leika birtubrigði gjarna stórt hlutverk. En um leið minnir orðið á umræðuna sem fram fer í bókinni um dökkt og ljóst litarhaft. Seinni merkingin, léttir, hefur aftur á móti verið túlkuð sem myndmál fyrir fæðingu, sbr. að verða léttari. Léttirinn hefur líka verið túlkaður í ljósi dauða Joes Christmas sem er leystur undan byrðum lífs síns. Pegar horft er á Af jörðu ertu kominn út frá peim andstæðupörum sem liggja Light in August til grundvallar lýkst upp merkingarheimur sem e.t.v. hefði verið lokaður að öðrum kosti. Titillinn Af jörðu ertu kominn vísar líka til upphafs jarðvistar mannsins pegar guð mótaði hann úr leir jarðarinnar og blés í hann lífi, pessi orð „Af jörðu ertu kominn“ eru höfð yfir börnum af prestum við skírn og peim látnu pegar peir kveðja jarðvistina sbr. „Af jörðu ertu kominn. Að jörðu skaltu aftur verða. Af jörðu skaltu aftur upp rísa.“ Titillinn á skáldsögu Guðmundar Daníelssonar vísar pannig bæði til vöggu og grafar, rétt eins og titillinn Light in August.

\section{III}

\section{Suðrið og norðrið}

Í bók sinni Iceland Imagined gengur sagnfræðingurinn Karen Oslund út frá kenningu mannfræðingsins Fredriks Barths um að sjálfsmyndir séu skapaðar á mærum, peim stöðum par sem mismunur á „pér“ og „öðrum“ sé greinilegastur. Samkvæmt pví eru viðhorf Evrópubúa til útjaðra heims- 
myndar peirra forsenda fyrir skilningi peirra á sjálfum sér og öðrum. ${ }^{41}$ Ein af pessum mærum eru á norðurhjara (e. North Atlantic), svæði sem Oslund lýsir sem útgarði (e. frontier) á jaðri Evrópu. Útgarðar á norðurhjara voru álitnir framandlegar óbyggðir af vestur evrópskum ferðalöngum sem fyrstir lögðu leið sína pangað og peir lýstu náttúrunni sem hættulegri og íbúunum sem óutreiknanlegum. Í bók sinni rekur Oslund hvernig pessi ímynd breyttist smám saman uns náttúra Íslands taldist fögur og viðráðanleg og íbúarnir einfaldir í háttum en dyggðugir. Samhliða pví sem ímyndin breyttist tóku samfélögin á norðurhjara skref í átt til nútímans í menningarlegu, umhverfislegu og tæknilegu tilliti. Prátt fyrir framandlega ímynd norðursins telur Oslund að alltaf hafi gætt nokkurrar óvissu um pað hvernig skyldi skilgreina svæðið út frá hinum „siðmenntaða heimi““.42 Ástæðan fyrir pessu var sú að landsvæðið var lítið og í raun ekki svo fjarri meginlandi Evrópu, íbúar Færeyja og Íslands voru ekki heldur frábrugðnir Vesturlandabúum í útliti og peir aðhylltust í flestum tilvikum sömu trúarbrögð. Af pessum sökum einkenndist sýn Vestur-Evrópubúa á norðrið ekki af eins skýrum andstæðupörum og pegar peir horfðu til Suður- eða Austurlanda. Pannig voru hugtök eins og „,við“ og „hin“, „heima“ og „,a heiman“ fljótandi. Önnur atriði voru notuð til að greina afbrigði frá evrópskum stöðlum, t.d. landslag og náttúra, tækni og efnismenning, tungumál og bókmenntir. Pessi atriði nýttust hins vegar ekki einungis evrópskum ferðalöngum á Norðurslóðum heldur voru pau líka notuð af heimamönnum til að skilgreina sig, pó fullyrða megi að báðir hópar hafi haft sinn skilning á í hverju mismunurinn var fólginn. ${ }^{43}$ Leit

41 Karen Oslund, Iceland Imagined: Nature, Culture, and Storytelling in the North Atlantic, Seattle og London: University of Washington Press, 2011, bls. 7.

42 Sama heimild, bls. 9-10.

43 Sumarliði R. Ísleifsson sagnfræðingur fjallar um ytri ímyndir Grænlands, Íslands og pjóðanna sem byggja pessar tvær eyjar í bók sem byggir á doktorsritgerð hans Tver eyjar á jaðrinum: Imyndir Íslands og Grenlands frá miðöldum til 19. aldar. Pó að sýn Íslendinga á eigin sjálfsmynd sé ekki sett á oddinn pá kemur hún víða við sögu til dæmis í kaflanum „Hin sið̋enntaða eyja - Fyrirmyndareyjan - Andsvör Íslendinga“, bls. 100-107. Sumarliði ræðir sköpun sjálfsmyndar og pau andstæðupör sem liggja henni til grundvallar rækilega í inngangskafla sem ber heitið: „Imaginations of National Identity and the North", og birtist í bókinni: Iceland and Images of the North, ritstj. Sumarliði R. Ísleifsson, ásamt Daniel Chartier, Québec: Presses de l'Université du Québec, 2011, bls. 3-22. Par er til umræðu pversagnakennd staða Íslands, í senn á jaðri og miðju sem líka er miðlæg í bókarkafla Ann-Sofie Nielsen Gremaud „Iceland as Centre and Periphery: Postcolonial and Crypto-colonial Perspectives“, The Postcolonial North Atlantic: Iceland, Greenland and the Faroe Islands, ritstj. Lill-Ann Körber og Ebbe Volquardsen, Berlin: Nordeuropa-Institut der Humboldt-Universität, 2014, bls. 83-104. Pjóðfræðingarnir Katla Kjartansdóttir 
Íslendinga að sjálfsmynd og tilraunir peirra til að skilgreina sig út frá andstæðupörum á borð við norður/suður, við/hin eru miðlæg umfjöllunarefni í príleik Guðmundar Daníelssonar Af jörðu ertu kominn. Birtast pau t.a.m. pegar samfélagsleg völd færast milli kynslóða í Eldi en kynslóðirnar spegla sig í ólíkum heimsmyndum par sem hugmyndir um miðju og jaðar, norður og suður eru breytilegar og skipta um inntak.

Mannfræðingurinn Kristín Loftsdóttir hefur fjallað um tengsl kynpáttahyggju og karlmennsku og bent á hvernig ímynd hins siðmenntaða Evrópubúa einkennist af áherslu á óttaleysi og pað hvernig karlmenn ryðji brautina fyrir framfarir á framandi slóðum. ${ }^{44}$ Pessa mynd má heimfæra upp á útgerðarmanninn Sögaard Nielsen í Eldi en hann er álitinn „velgjörðarmaður samfélagsins“, a.m.k. af vinum sínum og sagt er að fyrir hans daga hafi ríkt sultur í sveitinni. Hann skaffar mönnum atvinnu og færir peim björg í bú (E 56). Sá einstaklingur sem hagnast mest á veru hans í sveitinni er Jóhannes Jónsson pví Nielsen leigir af honum ströndina par sem íbúðarhús hans, fiskreitur, purrkatrönur og bátanaust standa (E 76). Vegna pessa ráðahags renna ríkulegir fjármunir til Jóhannesar sem gera pyngju hans gilda og hann sjálfan að æðsta embættismanni hreppsins (E 75). Jóhannes tilheyrir eldri kynslóð höfðingja sem kynntir eru til sögunnar í Eldi og pað sama á við um annan valdamikinn höfðingja í sveitinni, Sigurð í Nesi. Staða hans innan samfélagsins er líka tengd hinu erlenda valdi með afdráttarlausum hætti pví gjarna er vísað til hans sem „dannebrogsmannsins“ en heitið var notað um pá sem sæmdir höfðu verið silfurkrossi dannebrogsorðunnar (E 120). Рó að Nielsen tilheyri herrabjóðinni Dönum pá er íshafsströndin nú heimkynni hans og pegar hann situr að drykkju með Jóhannesi láta peir sig dreyma „stund og stund út úr ísnum, langt - langt inn í hitabelti hálfgleymdra minninga“ (E 87). Vínið sem peir drekka kemur úr suðri og pað kallar fram heillandi sýnir:

Róslituð ský yfir bláum unnum, hvítar kóralstrendur órafjarlægra eyja, svignandi pálmalundir og nakið fólk, sem dansar undir silfurfölri ásjónu mánans. Báðir hafa peir lifað pað að sjá dýrð suðursins með eigin augum, Jóhannes sem háseti á norsku skipi áður en hann

og Kristinn Schram hafa fjallað um pjóðernisímyndir og pjóðernislega sjálfsmynd í ýmsum greinum t.a.m. í eftirtöldum bókarkafla par sem pau beina sjónum að porrablótum í nútímanum: „Óræður arfur: Pjóð- og kyngervi dullendu í norðri“, Menningararfur á Íslandi: Greining og gagnrýni, ritstj. Ólafur Rastrick og Valdimar Tr. Hafstein, Reykjavík: Háskólaútgáfan, 2015, bls. 219-245.

44 Kristín Loftsdóttir, „Bláir menn og eykonan Ísland: Kynjamyndir karlmennsku og Afríku á 19. öld“, Ritið 2/2005, bls. 21-44, hér bls 42 . 
varð tvítugur að aldri, Sögaard Nielsen sem káetudrengur á einu af skipum Aust-indverska félagsins danska. (86)

Suðrið er ekki fastákvarðaður staður í textanum heldur kemur pað manni fyrir sjónir sem staðleysa. Samt sem áður teiknast upp í hugann heimsmynd par sem Danmörk hefur miðlæga stöðu en úti á jöðrunum eru hjá- og nýlendur hennar; Ísland, Grænland og Færeyjar í norðri en Dönsku VesturIndíur í suðri. Andspænis suðrinu eru Jóhannes og Nielsen samherjar, pað tengist reynsluheimi peirra beggja og kemur suðrið peim framandi en um leið heillandi fyrir sjónir. Upprifjun peirra á sameiginlegum minningum kemur heim og saman við rannsóknir í eftirlendufræðum á viðhorfum Evrópubúa til landsvæða eins og Asíu og Nýja heimsins pví viðhorf peirra til annarra varpa ekki síour ljósi á peirra eigin sjálfsmynd. Kristín Loftsdóttir hefur t.a.m. bent á pað hvernig pistlahöfundar Skirnis á nítjándu öld og byrjun peirrar tuttugustu samsömuðu sig Evrópumönnum í skrifum sínum um Afríku í peim tilgangi að styrkja eigin sjálfsmynd sem siðmenntaðra manna, liður í pví var að lýsa Afríkubúum sem ósiðuðum villimönnum. ${ }^{45} \mathrm{Nakta}$ fólkið sem Nielsen og Jóhannes sjá fyrir sér, dansandi á pálmaströnd, er annarlegt, pað er „hinir“ og staðfestir í krafti mismunar pað sem peir eru sjálfir, „við““. ${ }^{46}$ En prátt fyrir að Ísland sé uppspretta auðæfa Nielsens pá streitist hann gegn pví að festa par rætur: „Рað var eins og hann vildi ekki eiga hina íslenzku jörð, sem hann hafði undir sínum dönsku fótum“ (E 76). Og pær nútímalegu breytingar sem hann gerir á efnahagslífi og tæknimenningu byggðarlagsins eru af pessum sökum aðeins yfirborðslegar eins og sést pegar hann deyr og allt er flutt á brott: „bátarnir, veiðarfærin, aflinn, búslóðin og jafnvel sjálft íbúðarhúsið“ (E 89). Eftir stendur ströndin „[a]uðari og nöturlegri“ en hún hefur verið nokkru sinni fyrr: „ber eins og rænt og limlest lík á eyðislóðum“ (E 89). Pegar kaupmannsins nýtur ekki lengur við hefur Jóhannes ekki aðeins misst fjárhagslegan bakhjarl sinn heldur líka bann sem hann samsamaði sig með og grundvallaði sjálfsmynd sína á, hann er einn „harmprungnari en allir aðrir, sekari, iðrunarfyllri og eyðilagðari en nokkur annar hinna afskekktu strandbúa norður við Íshafið“ (E 89). Pessa mynd af Íslandi má tengja lífseigum hugmyndum um ímynd norðursins en eins og sagnfræðingurinn Sumarliði Ísleifsson hefur benti á var norðrið gjarna álitið

45 Karen Oslund, Iceland Imagined: Nature, Culture, and Storytelling in the North Atlantic, bls. 9.

46 Sjá, Kristín Loftsdóttir, „Bláir menn og eykonan Ísland: Kynjamyndir karlmennsku og Afríku á 19. öld”, bls. 42. 
ríkt af auðæfum en íbúar pess of frumstæðir til að hagnýta sér pau. ${ }^{47}$

Pó að Nielsens njóti ekki lengur við heldur Jóhannes áfram að misnota áfengi og einangrast sífellt meir og meir. Baráttan gegn áfengisneyslu Íslendinga hefur verið skoðuð sem hluti af sjálfstæðisbaráttu pjóðarinnar og hún sett í samhengi við ímynd Dana sem nýlenduherra og Íslendinga sem undirsáta peirra. Sumarliði Ísleifsson heldur pví fram að áfengi hafi verið „aðrað“ (e. othering) og tengt danskri kúgun. Að hans sögn voru peir sem börðust gegn áfengisbanni sagðir vera undir dönskum áhrifum og var drykkju enn fremur lýst sem einkenni á skrælingjum og ósiðmenntuðum pjóðum. ${ }^{48}$ Pessa togstreitu má greina í Eldi pví pegar fram líða stundir er Jóhannesi lýst sem barni annarrar aldar (E 125). Nýi tíminn tilheyrir syni hans, Jónasi Jóhannessyni, sem berst fyrir bindindi og bættum siðum í sveitinni. Hann leiðir ungmennafélagið í Neshreppi og fer í lýðháskóla í Ásaskógi og minnir mjög á nafna sinn Jónas Jónsson frá Hriflu að pví leyti að hann ætlar að sækja pangað „neista af eldi lærdóms og menningar, sem síðan skyldi tendraður á pessari norðlægu strönd, svo að víða lýsti af “ (E 115). Kjörorð Jónasar í skáldsögunni eru „Sterkari samtök, meiri félagsskapur, aukin alpýðumenntun," (E 125) en til að ná fram pessum markmiðum sínum hyggst hann reisa bæði samkomuhús og skólahús að Sævarhóli. Staða launsonar Nielsens, Gísla í Gröf, er athyglisverð í pessu samhengi pví hann bruggar á laun rétt eins og Joe Christmas í Ljósi i ágúst.

Prátt fyrir að uppbyggingarstarf Jónasar í sveitinni sé göfugt pá er hann líka yfirgangssamur og ekki geðfelld persóna að öllu leyti. Valdsmannslegir eiginleikar hans eru undirstrikaðir með pví að tengja hann danska konungsveldinu á táknrænan hátt. Pegar Jónas er sjálfur orðinn hreppstjóri og oddviti í sveitinni, kemst hann að leyndarmáli Gísla og föður síns um bruggið. Hann bregst við með pví að gera sér ferð að Gröf par sem hann gerir bruggtækin upptæk. Pegar Jónas kemur af fjalli ásamt fylgdarmanni sínum mæta peir Jóhannesi og pá koma peir honum fyrir sjónir með eftirfarandi hætti: „Vínsuðubrúsar og prímusvélar Gísla í Gröf dingla framan á peim eins og fáránlegar, yfir sig vaxnar og vanskapaðar orður. Рað er búið að gera pá að dannebrogsmönnum!“ (E 133). Með pví að gera framleiðslutæki áfengis-

47 Sumarliði R. Ísleifsson, Tvar eyjar á jaðrinum: Ímyndir Íslands og Grenlands frá miðöldum til miðrar 19. aldar, bls. 37.

48 Sumarliði R. Ísleifsson, „"In Comes Wine, Out Goes Wit”: Icelandic Independence and Prohibition of Alcohol“, Encountering Foreign Worlds; Experiences at Home and Abroad, ritstj. Christina Folke Ax, Anne Folke Henningsen, Niklas Thode Jensen, Leila Koivunen og Taina Syrjämaa, Ritsafn Sagnfræðistofnunar, Reykjavík: Háskólaútgáfan, 2007, bls. 13-24, hér bls. 19-21. 
ins upptæk má segja að Jónas skrúfi fyrir dönsk áhrif. Sá lestur er vissulega pversagnakenndur í ljósi pess að hann sækir sér menntun til Danmerkur og pannig spretta hugmyndir hans úr dönskum jarðvegi, hið nýja veldi sem hann ætlar sér að byggja rís sömuleiðis á dönskum grunni „par sem áður stóðu fisktrönur Sögaards Nielsen“ (E 144). Sævarhóll heldur sem sé áfram að vera miðpunktur sveitarinnar en önnur heimsmynd birtist peirri kynslóð sem tekur við af Jóhannesi, Nielsen og Sigurði í Nesi. Í henni tengist suðrið ekki annarlegum Suðurhafseyjum heldur hinni nýju valdamiðju á Íslandi, p.e.a.s. höfuðborginni Reykjavík. Par er ekki aðeins að finna pólitískt vald heldur er borgin líka miðstöð vísindalegrar pekkingar. Pegar Solveig heitkona séra Gylfa fellur í dá er almannarómur látinn enduróma í textanum: „,'Suður“, segir fólkið. Suður, suður, pangað sem læknarnir geta allt, jafnvel vakið upp af dauðasvefni“ (E 122). Séð frá Reykjavík er Sævarhóll hins vegar ekki miðja heldur jaðar og kemur jaðarsetning byggðarlagsins m.a. fram í pví að vandræðaunglingnum Halli Jenssyni „er komið úr bænum“ til Jónasar sennilega fyrir milligöngu lögregluyfirvalda (E 206). Unglingurinn endurspeglar nútímann í Reykjavík en í svo öfgafullri mynd að pað verður að senda hann í betrunarvist í sveitina. Helsta einkenni Halls er eirðarleysi pví hann japlar „hvíldarlaust á sælgætinu sínu“ og pað er eins og hann vilji sjúga „úr pví eitthvað sem aldrei hafði verið í pað látið“ (E 205). Síðar er vakin athygli á „slangrandi göngulagi, hinu eirðarlausa rangli hans um hlöðin, hinum síjaplandi munni og rauðu, votu vörum“ (206-207). Sjálfum líst unglingnum ekki allt of vel á sveitina:

Reykvíkingurinn reis á fæur. „Helvítis pláss er petta, bara for og bleyta og fjósalykt", sagði hann og gretti sig. Hann hafði laglegt andlit, en munnsvipurinn var seyrinn og tennurnar skemmdar. Í augum hans var ekkert að sjá, enga sorg, enga gleði, aðeins grábláa poku. Svo tróð hann enn einu sinni munninn fullan af sælgæti, tók pví næst töskuna sína og hélt af stað heim til bæjarins... (E 205)

Hin slæma tannhirða Reykvíkingsins stafar ekki af bágri félagslegri stöðu pví foreldrar Halls eru sagðir „ríkir og vel metnir í höfuðstaðnum“ (E 206). Pegar sælgætið klárast grípur hann til örprifaráða til að komast aftur heim pví pað er hann sem kveikir í nýbyggðu skólahúsinu sem brennur til kaldra kola. Afstaða Jónasar til Halls var skýr í upphafi: „Hann hefur lent í lítilsháttar klandri fyrir sunnan, en hann skal verða lagaður hérna“ (E 107). Manni getur virst sem sagan bjóði upp á hefðbundnar andstæður sveitar og borgar par sem borgin býður tæknilegar lausnir á líkamlegum veikindum 
meðan sveitalífið greiðir úr sálarflækjum og innrætir peim sem hafa villst af braut góða siði. Pessi andstæða er hins vegar bara á yfirborðinu pví í sveitinni er ekki allt með felldu. Enginn veit bað jafnvel og Jóhannes sem hugsar með sér á ákaflega Faulkneríska vísu: „... syndir feðranna koma niður á börnunum í priðja og fjórða lið“ (E 178).

Pegar skóla- og samkomuhúsið eru brunnin halda smiðirnir sem unnu verkin heim á leið, yfirsmiðurinn er sannfærður um að „djöfullinn sjálfur regeri á pessu bölvaða nesi“, honum virðist pykja miður að starf peirra hafi verið til einskis en félagi hans lætur sér pað í léttu rúmi liggja: „Skítt með pað; við höfum fengið okkar peninga“, að svo mæltu héldu peir áfram og „stefndu til suðurs“ (E 235). Útgarðurinn hefur sem sé aftur kallað til sín menn sem vilja auðgast en pegar hörmungar dynja yfir er byggðin á jaðrinum jafn illa sett, sama hvort miðjan sem dregur til sín féð er Kaupmannahöfn eða Reykjavík.

\section{Svartar fléttur, málleysi og sveppa varir}

Bókmenntafræðingurinn John T. Matthews hefur fjallað um samspil kynpáttar, kynferðis og kynlífs í Ljósi i ágúst. Hann heldur pví fram að sögupersónur Faulkners skilgreini sjálfsmynd sína út frá pessum báttum og horfir til kenninga Freuds annars vegar og hins vegar aldalangrar sögu prælahalds í Suðurríkjunum. Matthews segir að rétt eins og karlmenn skilgreini kynferði kvenna út frá vöntun á getnaðarlim í freudískum skilningi pá skynji hvíti maðurinn litarhaft peirra svörtu sem spilltan hvítleika. Pessi sýnilegi munur á svörtum og hvítum hafi sömuleiðis verið notaður til að réttlæta prælahaldið í Suðurríkjunum. Til að viðhalda skýrri aðgreiningu húsbænda og præla voru sett ströng lög til að hamla gegn blöndun kynpáttanna og sjálfsmynd hvíts gagnkynhneigðs fólks var grundvölluð á ströngum skilyrðum um samneyti við svarta. Pannig áttu eiginkonur og mæður plantekrubænda að forðast kynferðismök við svarta og afkvæmi hvítra húsbænda og svartra præla bar að líta á sem ómerkinga (e. nonentities). Boð og bönn frelsuðu hina hvítu ekki undan allt að pví práhyggjukenndum hugmyndum um yfirburða hæfileika svartra á kynlífssviðinu en pær ásóttu jafnt hvíta karla og konur. ${ }^{49}$ Ein af kenningum Matthews gengur út á að í Ljósi i ágúst afhjúpi Faulkner vitneskju

49 John T. Matthews, "This Race Which Is Not One: The "More Inextricable Compositeness" of William Faulkner's South“, Look Away!: The U.S. South in New World Studies, ritstj. John Smith og Deborah Cohn, Durham: Duke University Press, 2004, bls. 201-26, hér bls. 202. 
hvítra íbúa Suðurríkjanna um pað að munurinn á svörtum og hvítum byggi á skáldskap en ekki veruleika. Hann heldur pví enn fremur fram að Faulkner sé ekki upptekinn af ómeðvituðum, bældum eða pögguðum sannleika í pessari skáldsögu heldur hinum próuðu félags- og sálfræðilegu aðferðum sem gerðu hvítum kleift að viðhalda og vernda yfirburði sína, prátt fyrir að peir væru augljóslega byggðir á sandi. ${ }^{50}$ Í pessu sambandi beinir Matthew sjónum sínum sérstaklega að blæti. Í freudískum skilningi er pað hlutur eða fyrirbæri sem hefur tvípætta merkingu; annars vegar staðfestir hluturinn eða fyrirbærið vitund mannsins um vöntun kvenna á getnaðarlim; hins vegar bætir hluturinn eða fyrirbærið upp fyrir skortinn og tengist kynferðislegri nautn. ${ }^{51}$ Í greiningu sinni byggir Matthews líka á kenningum indverska bókmennta- og eftirlendufræðingsins Homis K. Bhabha en hann hefur skoðað staðalmyndir um kynpætti sem blæti og haldið pví fram að staðalmyndin sé forsendan fyrir sjálfsmynd nýlendubúans og nýlenduherrans vegna pess að hún skilgreini eiginleika kynpáttanna. Andspænis svörtum ómerkingi fái hinn hvíti staðfestingu á augljósum og náttúrulegum hreinleika sínum. En sem blæti byggi staðalmyndin á órum og sem slík búi hún yfir pví sem Freud kallaði samtímatilvist gagnstæðra hneigða, afstöðu eða tilfinninga til sama viðfangs; samkvæmt Bhabha er samtímatilvist staðalmynda fólgin í pví að hún elur á ótta við mismuninn en örvar um leið óra um kynferðislega nautn. ${ }^{52}$

Matthews notar kenningar Bhabha til að greina samskipti Joes Christmas við ýmsar persónur Ljóss í ágúst, m.a. við Joanna Burden. Sú greining sýnir fram á hvernig pau gangast upp í að leika tilteknar staðalmyndir til að magna upp forboðna kynferðislega spennu. Í leiknum læðist Christmas inn í hús Burdens, eins og pjófur að nóttu, enda pótt hún búist við honum og láti eins og hann sé að ræna hana meydómnum nótt eftir nótt. Pannig gengur hann inn í hlutverk pess svarta en ímyndar sér um leið að Burden sé húsfreyja á plantekru sem vekur losta hans. Á sama tíma lætur hún eins og samræðið sé henni á móti skapi og berst á móti meðan hún æpir: „Negro! Negro! Negro!“ (LA 590). Síendurteknar athafnir festa staðalímyndirnar í sessi að mati Bhabha og hamla gegn pví floti sem er á sjálfsmyndum manna í samfélögum blandaðra kynpátta. ${ }^{53}$ Í Af jörðu ertu kominn má finna dæmi um að staðalmyndir séu notaðar til að undirstrika eða réttlæta valdaójafn-

\footnotetext{
50 Sama heimild, bls. 204.

51 Sama heimild, bls. 202.

52 Sama heimild, bls. 205.

53 Sama heimild, bls. 205.
} 
vægi. Á ritunartímanum er hæpið að hægt sé að tala um svarta sjálfsmynd á Íslandi sem var einsleitt samfélag pegar horft er til kynpáttar og pjóðernisuppruna. ${ }^{54}$ I príleiknum verða smávægileg frávik í útliti að kynpáttamarki en aðrar mismunarbreytur skipta líka máli. Hér á eftir verða tekin tvö dæmi, annars vegar verður horft á Guðrúnu móður Gísla í gröf sem hefur jaðarstöðu vegna kynferðis og fötlunar. Hún er mállaus en hefur að auki svarta fléttu sem virðist eiga stóran pátt í kynferðislegu aðdráttarafli hennar. Hins vegar verður horft á vinnumanninn Tomma í Landinu bandan landsins en athygli lesandans er ítrekað dregin að vörum hans, smám saman verður ljóst að um kynpáttamark er að ræða pví persónulýsing hans tekur mið af staðalímyndum blökkumanna. Staðalmyndirnar og valdaójafnvægið sem pær byggja á verða skýrust pegar hinir undirskipuðu eru beittir kynferðislegu ofbeldi sem undirstrikar um leið félagslega yfirburði gerendanna.

Í Eldi gengur Guðrún inn á sögusviðið með diska og hnífapör á heimili Sögaards Nielsen par sem hann situr að drykkju ásamt Jóhannesi. Valdaójafnvægið milli peirra kemur skýrt fram pegar Guðrún nemur staðar og lítur „spyrjandi á húsbónda sinn“ (E 57), sem bregst við með pví að kinka kolli án pess að yrða á hana. Hún flýtir sér að leggja á borð, hraðar sér síðan fram til að sakja meira. Fyrst í stað er Guðrún ekki nefnd á nafn í textanum en pegar pað er gert er starfstitill hennar tilgreindur fyrst og síðan nafnið: „Petta var vinnukonan, Guðrún“ (E 57). Á eftir fylgir nánari lýsing á henni sem er afmörkuð með gæsalöppum til að gefa til kynna að um almannaróm sé að ræða: „mállausa stúlkan með löngu flétturnar svörtu.“ Áherslan á svartan hárlit er líkleg til að leiða hugann á suðrænar slóðir og virðist meðvitund um pað búa í textanum pví í beinu framhaldi er sérstaklega tekið fram: „Annars var hún vestfirzk“ (E 57). Orðræðan um Guðrúnu hefur eiginleika blætis pví hún er sprottin af hugarórum karlmanna sem glápa á hana og koma orðrómnum af stað. Um leið er Guðrún forboðin pví hún er ástkona danska húsbóndans. Nielsen afsalar sér öllu frumkvæði í barnsmálinu og lætur bað í hendur Jóhannesar; ákvörðunin tekur á útgerðarmanninn danska en engu að síður virðist afstaða hans til stúlkunnar vera sú að hann geti ráðstafað henni eins og hverri annarri eign. Pannig er komið fram við hana eins og præl eða ómerking fremur en frjálsa manneskju sem lýsir sér meðal annars í pví að Jóhannes býður Runólfi Sveinssyni að ganga að eiga Guðrúnu gegn mútum

54 Kristín Loftsdóttir og Unnur Dís Skaptadóttir, „Ísland í heiminum og heimurinn í Íslandi“, Ísland í heiminum og heimurinn i Íslandi, ritstj. Kristín Loftsdóttir, Unnur Dís Skaptadóttir og Anna Lísa Rúnarsdóttir, Reykjavík: Pjóðminjasafn Íslands, 2016, bls. 7-21, hér bls. 13-14. 
og án pess að hún sé höfð með í ráðum.

Shaun Grech hefur fjallað um tengsl nýlendustefnu og fötlunar. Рó að skrif hans fjalli um hið hnattræna suður má heimfæra margt í greiningu hans upp á aðstæður Guðrúnar. Pannig bendir hann á að prælasala hafi ýtt undir staðlaða sýn á líkama nýlendupegnsins; stórir, sterkir og vinnufærir menn sem færðu húsbændum sínum fjárhagslegan ávinning voru eftirsóknarverðir. Peir sem ekki uppfylltu skilyrðin voru minna virði og fengu lægri stöðu í peirri stigskipun sem valdakerfi nýlenduherrans byggði á. Mismunarbreytur eins og kyn, fötlun og kynpáttur gáfu tilefni til aðgreiningar, jaðarsetningar og jafnvel útilokunar. ${ }^{55}$ Nálgun Grechs má tengja við samtvinnun eða skörun (e. intersectionality), hugtak sem á rætur að rekja til baráttu svarta femíníska lögfræðingsins Kimberlé Crenshaw fyrir réttindum svartra kvenna. ${ }^{56} \mathrm{Hug}-$ takið hefur náð mikilli útbreiðslu undanfarna áratugi og verið notað m.a. í fötlunarfræðum, kynjafræðum og lögfræði. Kynjafræðingurinn Porgerður H. Porvaldsdóttir hefur skilgreint hugtakið á íslensku með eftirfarandi hætti:

Samtvinnun hefur verið notuð sem kenning og aðferðafræði til pess að skoða hvernig félags- og menningarbundin valdamismunun, sem verður til í kringum stofnanabundnar og/eða félagsmótaðar breytur byggðar á kyngvervi, pjóðerni, kynpætti, stétt, kynhneigð, fötlun, heilsu, aldri, stétt, trúarbrögðum, búsetu o.s.frv. samtvinnast og móta hver aðra, og skapa par með ný form af félagslegum ójöfnuði og mismuni. ${ }^{57}$

Pegar við skoðum Guðrúnu með augum Jóhannesar, sem tilheyrir yfirstéttinni, sjáum við að stúlkan hefur margháttaða jaðarstöðu í samfélaginu, pannig tvinnast saman stéttarstaða hennar, kynferði og fötlun. Hún er „mállaus vinnukona“ og að auki ógift. Pegar í ljós kemur að hún gengur með

55 Shaun Grech, „Decolonising Eurocentric disability studies: why colonialism matters in the disability and global South debate“, Social Identities 21: 1/2015, bls. 6-21, hér bls. 10-11. Nirmala Erevelles og Andrea Minear fjalla líka um náin tengsl mismunarbreytanna kynpáttar og fötlunar í greininni: „Unspeakable Offenses: Untangling Race and Disability in Discourses of Intersectionality“, Fournal of Literary \& Cultural Disability Studies 4: 2/2010, bls. 127-145.

56 Porgerður H. Porvaldsdóttir: „„,Pí miður eruð pér ekki á kjörskrá.“ Samtvinnun sem greiningartæki í sagnfræði“, Saga: Tímarit Sögufélags 55: 1/2017, bls. 74-112, hér bls. 78-79.

57 Sama, bls. 80. Samtvinnun er líka lykilhugtak í grein sagnfræðingsins Írisar Ellenberger, „Lesbía verður til: Félagið Íslensk-lesbíska og skörun kynhneigðar og kyngervis í réttindabaráttu á níunda áratug 20. aldar“, Saga: Tímarit Sögufélags 54: 2/2016, bls. 7-53. 
barn Nielsens brýnir Jóhannes fyrir honum að hann geti ekki gifst Guðrúnu með peim rökum að „pá smán“ myndi hann „aldrei vilja gera konunni [s]inni sálugu og syni“ (E 60). Í augum Jóhannesar er Guðrún „aumingi að vissu leyti“ en ekki öllu pví hún er vinnufær og fötlun hennar er ekki sýnileg. Runólfur setur aðeins eitt skilyrði fyrir samkomulaginu við Jóhannes og Nielsen en pað er að hann fái „kvenmanninn strax“ (E 67). Petta sampykkja peir en lýsingin á pví pegar peir leiða Runólf á fund Guðrúnar er löng og spennuprungin og kallast að vissu leyti á við pað pegar Joe Christmas læðist um herragarð Joanna Burdens. Á stöðu Joanna og Guðrúnar er pó grundvallar munur sem kemur skýrt fram í pví að sú fyrrnefnda er frjáls kona í eigin húsi meðan komið er fram við pá síðarnefndu sem eign húsbónda síns. Grech bendir á að nýlendustefnan hafi endurskilgreint hlutverk og stöðu kynjanna og breytt hefðbundnum fjölskyldumynstum. Hún hafi enn fremur aukið líkur á kynferðisofbeldi sem fatlaðar konur er sérstaklega útsettar fyrir. ${ }^{58}$ Guðrún býr einmitt ein í herbergi í húsi Sörensens og par finna mennirnir hana í hnipri. Hún reynir að „hylja bert brjóst sitt bak við krosslagða handleggina og svartar fléttur, sem héngu eins og digrir kaðlar fram yfir axlir hennar“ (E 70). Áður en Runólfur nauðgar Guðrúnu spyr hann hana: „Veiztu, hvað við höfum kallað pig niðri í verbúðunum?“ (E 72). Lýsingin á viðbrögðum hennar sýnir greinilega lömunartilfinningu sem polendur kynferðisofbeldis lýsa gjarna en um leið er hún hlutgerð í peirri mynd sem blæti mannanna hefur tekið á sig: „Hún starði fram hjá honum svipbrigðalaus eins og mynd og skildi ekki hvað hann átti við“ (E 72). Runólfur svarar svo sjálfur spurningunni sem hann lagði fyrir hana: „Mállausu stúlkuna með löngu flétturnar svörtu“ (E 72). Runólfur gengur hér inn í óra sína og hefur samræði við ástkonu húsbóndans. Með pví tekur hann sér drottnandi stöðu yfir ógiftri vinnukonu sem getur ekki svarað fyrir sig vegna málleysis og virðist tengjast staðalímynd suðrænnar ástmeyjar í hans huga. Samræðið er án sampykkis, pað er nauðgun, og pannig opinberar blætið ekki aðeins ofbeldismanninn Runólf heldur líka Jóhannes og Nielsen sem selja hana í hans hendur í krafti peirra valda sem peir hafa í samfélaginu. Pessi ákvörðun hefur samt sem áđur djúpstæð áhrif á Nielsen og rödd hans fær tón „sem barst eins og frá enn dýpra hljómgrunni en hinn danski hreimur hennar, alla leið paðan, sem kvika sálarinnar liggur og pjóðernislegur uppruni nær ekki til““ (E 68). Rödd hans býr enn yfir pessum tóni pegar hann flytur kveðjuræðu yfir Guðrúnu:

58 Shaun Grech, „Decolonising Eurocentric disability studies: why colonialism matters in the disability and global South debate“, bls. 15 . 
„Guðrún“, sagði hann, „Runólfur Sveinsson er kominn hér til að biðja pín. Hann vill giftast pér og gera pig að húsmóður í Gröf. Hann er að vísu innbrotspjófur og ræningi og mun eflaust mispyrma pér og gera líf pitt að píslargöngu, en pað er sama; mig skortir dáð og hugrekki til að forða pér frá pessu. Рað er glæpur og ég játa hann á mig, og ég veit, að fyrir guði og fyrir pér mun ég verða sekari fundinn heldur en peir, sem á augljósari hátt kunna að verða böðlar pínir á lífsleiðinni, pví ef til vill vita peir ekki, hvað peir gera, en pað veit ég.“ (E 71)

Píslarganga Guðrúnar, mállausu stúlkunnar með löngu flétturnar svörtu varð ekki löng pví hún dó af barnsförum en segja má að sonur hennar hafi tekið við krossinum og borið hann til grafar. Hörmunginni er bó ekki lokið pví mennirnir sem gerðu uppeldisföður Gísla að nauðgara og böðli skapa honum sömu örlög. Pannig er hið liðna ekki liðið meðan samfélagið gerir ekki upp við glæpi fortíðarinnar.

Í lokabindi príleiksins, Landinu handan landsins, er að finna frásögn sem kveðst á við sögu Guðrúnar. Í upphafi eru lesendur kynntir fyrir persónu sem í fyrst í stað er eingöngu nefnd „húsbóndinn“ en stuttu síðar kemur í ljós að hér er á ferðinni Hrólfur, bróðir séra Gylfa og sonur dannebrogsmannsins Sigurðar í Nesi. Hrólfur er staddur í svefnherbergi sínu og fylgist út um glugga með fimmtán ára gömlum vinnumanni sínum Tomma Tuma sem reynir að teyma brúnblesóttan fola að hestasteini sem stendur á hlaðinu. Tommi notar orðið „húsbóndi“ pegar hann vísar til Hrólfs (L 5) en unglingnum er lýst pannig að hann hafi farið sér „hægt að öllu“, hann blístrar danslag og pá er athyglin dregin sérstaklega að vörunum á honum: „Pykkar varirnar á honum stóðu út í loftið eins og rauð kúla úttroðin af danslögum, og hann slöngvaði peim frá sér hverju á fætur öðru með takti og trillum. Makalaust að geta annað eins með munninum, - næstum eins og hljóðfæri væri í honum, hehe!“ (L 6). Síðasta athugasemdin minnir á lýsingu vinnukonunnar Guðrúnar „Mállausu stúlkunnar með löngu flétturnar svörtu“ að pví leyti að hún virðist endurómur af almannarómi. Í lýsingum á Tomma er klifað á pessum atriðum, við hittum hann næst fyrir par sem hann liggur á maganum úti á túni og pá er athyglin enn og aftur dregin að vörunum: „Út á milli rauðra sveppavaranna á honum lagði mórauður hnakkólarspotti, sem hann var að tyggja“ (L 10). Tommi er sagður hafa dökkan hárdún á hökunni og sömuleiðis eru augnabrúnir hans pétthærðar og dökkar. Pað er hins vegar ekki fyrr en síðar að litarhafti hans er lýst og pá eftir að hann hefur erfiðað 
úti við ásamt húsbóndanum og öðru vinnufólki: „Andlitið á honum, sem undir venjulegum kringumstæðum var rautt, einkum varirnar, var orðið sótrautt um hádegi og dökknaði pó meir eftir pví sem á daginn leið“ (L 60). Tommi ber sig vel par til annar vinnumaður tekur að stríða honum og uppnefnir hann „glóðarhaus“. Pá bregst Tommi við með pví að hrækja í áttina að vinnumanninum tóbaki af gerðinni Brödrene Braun. Pessi tiltekna gerð tóbaks naut mikilla vinsælda á Íslandi og er ítrekað tengd Tomma. Sé ættarnafnið Braun skilið bókstaflega er nafn tóbaksins Bræðurnir Brúnu.

Hafi lesendur verið farið að renna í grun um að lýsing Tomma markist leynt og ljóst af staðalímynd blökkumanna, náskyldri persónum á borð við Sam í Kofa Tómasar frenda eftir Harriet Beecher Stowe, pá eru tekin af öll tvímæli pegar kaupakonan Heiðrún, sem húsbóndinn Runólfur hefur augastað á, segir hreint út: „Tommi Tuma, pú hefur varir eins og negri“ (L 136). Heiðrún hafði skömmu áður beðið Tomma um að dansa við sig og farið um hann höndum. Rétt eins og Guðrún frýs Tommi pegar hafðir eru í frammi kynferðislegir tilburðir. Hann: „á ekkert orð í bili, en stendur parna galdri sleginn og má sig ekki hræra. Og hann kennir mjög undarlegrar tilfinningar víðs vegar um líkamann, einkum hinum viðkvæmari hlutum hans, svo sem tám og fingrum og víðar - eins og ótal æðar taki að slá par“ (L 136). Heiðrún líkir Tomma við negra í pann mund sem hún kyssir hann og pannig fer saman kynferðisleg athöfn og uppljóstrun um blæti sem tengist kynpáttamarki. Viðbrögð Tomma eru reiði, hann vill hefna sín grimmilega en „í ráðprota bræði sinni grípur hann einn bollann af borðinu og grýtir honum af alefli í gólfið. Á næsta augnabliki er hann horfinn út um dyrnar.“

Heiðrún hefur ekki sams konar yfirburðastöðu gagnvart Tomma og peir Runólfur, Jóhannes og Nielsen gagnvart Guðrúnu en pegar parna er komið sögu er Heiðrún tekin að máta sig við hlutverk húsfreyjunnar á heimilinu. Kossinn er pannig ekki milli tveggja jafningja heldur til pess fallinn að staðfesta mun á henni og öðru heimilisfólki sem hlær að tiltækinu og viðbrögðum Tomma. Heiðrún finnur líka til sín vegna pess valds sem hún hefur yfir honum: „Hún hafði snert sálina í pessum litla, úfinhærða pilti og kveikt í henni eld, - séð hana inni í augum hans, hvernig hún stirðnaði upp sem snöggvast við snertinguna, unz hver kennd hennar tók viðbragð og eldurinn læsti sig um hana alla“ (L 137). Yfirburðir hennar eru svo staðfestir enn frekar pegar fundum hennar og Tomma ber næst saman en pá hefur Hrólfur boðið henni á dansleik. Tommi parf að pjóna peim báðum með pví að gera hesta peirra tilbúna til reiðar. Skömmu áður hafði athyglin enn og aftur verið dregin að munni Tomma og tóbaksneyslu hans en pá er tóbakið í fyrsta skipti tengt 
pjóðerni pegar Brödrene Braun er kallaður: „hinn brúni, danski vökvi“ (L 141). Hér kann lesandi að hugsa til pess með hvaða hætti áfengi og neysla pess var talið til marks um stöðu Dana sem nýlenduherra en Íslendinga sem undirsáta peirra. Ef notast er við margpvælda líkingu mætti segja að Tommi sé præll fíknar sinnar, einn af brúnu bræðrunum í nýlendum Dana. „Húsbóndi“ Tomma er hins vegar ekki danskur útgerðarmaður eins og í tilfelli Guðrúnar heldur íslenskur stórbóndi, sonur dannebrogsmannsins Sigurðar í Nesi. Rétt eins og miðja valdsins færist frá Kaupmannahöfn „suður“ til Reykjavíkur pá tekur ný kynslóð við völdum í sveitinni og par virðast flokkunarkerfi nýlenduhyggjunnar vera notuð til að raða fólki í virðingarstiga par sem tvinnast saman pættir eins og félagsleg staða, kynferði, fötlun og útlitseiginleikar.

\section{IV}

Rannsóknir fræðimanna, eins og Pascale Casanova, Deborah Cohn og Hosam Aboul-Ela, á verkum höfunda sem unnið hafa úr arfleið Faulkners gefa tilefni til að skoða príleik Guðmundar Daníelssonar í samhengi við fortíð Íslands sem nýlendu Dana. Hið margbrotna samfélag Suðurríkja Bandaríkjanna, sem Faulkner fjallaði um í verkum sínum, má einungis heimfæra upp á Ísland að takmörkuðu leyti en Guðmundur vinnur úr áhrifum Faulkners og afhjúpar hvernig mismunarbreytur eins og fötlun, kynpáttamörk, kynferði og stétt tvinnast saman og eru notaðar til aðgreiningar og stigskipunar í íslensku samfélagi. Í Ljósi i ágúst er reynt að halda faðerni Joes Christmas leyndu vegna pess að grunur leikur á að um æðar hans renni svart blóð. Í Eldi hvílir líka leynd yfir pví að Gísli í Gröf sé afkomandi dansks kaupmanns en ástæða pess er sú að íslenskur héraðshöfðingi vill standa vörð um óbreytt valdakerfi, óttinn er pví ekki við útlendinginn heldur Guðrúnu, íslenska konu af lágum stigum. Málleysi hennar og svört flétta virðast eiga stóran pátt í kynferðislegu aðdráttarafli hennar, mögulega vegna pess að pessa pætti má tengja staðalmyndum Suðrænna kvenna. Í Landinu handan landsins eru varir vinnumannsins Tomma ótvírætt kynpáttamark sem notað er til að jaðarsetja hann og undirstrika valdamisræmi milli hans og annarra íbúa á bænum. Bæði pessi dæmi sýna að mínu viti andlegan skyldleika við verk Faulkners, hugvitsamlega endursköpun á pví arfbundna valdamisrétti sem býr í samfélagsgerð Suðurríkjanna. Á sama tíma er íslensk yfirstétt tengd dönsku valdi, bæði með tilvísun til sameiginlegs reynsluheims par sem hugmyndir um suður, norður og íbúa pess gegna lykilhlutverki en líka með hugtökum eins og „danne- 
brogsmaður“ og „húsbóndi“ sem íslensk yfirstétt piggur í arf pó hún berjist fyrir nýjum tímum, að minnsta kosti í orði kveðnu.

Príleikur Guðmundar Daníelssonar er ekki gallalaus en hann er forvitnilegt rannsóknarefni og er til vitnis um pau gríðarlegu áhrif sem bandarískar bókmenntir höfou á íslenska höfunda í kjölfar albjóðlegs gegnumbrots peirra í upphafi fjórða áratugar síðustu aldar. Um leið segir saga Guðmundar af menningarreisunni til Kaupmannahafnar og kynnum hans af Faulkner í norskum pýðingum okkur að Norðurlönd pjónuðu hlutverki nokkurs konar glugga að umheiminum fyrir Íslendinga lengi fram eftir 20. öldinni. Og pegar hugsað er um íslenskar bókmenntir á 20. öld, og pað umhverfi sem höfundar og lesendur hrærðust í, nægir ekki að huga að frumsömdum textum og pýðingum á íslensku heldur verður líka að taka tillit til bókmennta á öðrum tungumálum sem stóðu peim til boða.

\section{ÚT D RÁT T UR}

\section{Frá suðri til norðurs William Faulkner og Guðmundur Daníelsson}

Á fyrri hluta fimmta áratugarins skrifaði Guðmundur Daníelsson skáldsagna príleikinn Af jörðu ertu kominn: Eldur (1941), Sandur (1942) og Landið bandan landsins (1944). Guðmundur fór aldrei í grafgötur með pað að kynni hans af skáldsögum bandaríska rithöfundarins William Faulkners, í norskum pýðingum á fjórða áratugnum, hefðu haft afgerandi áhrif á gerð príleiksins en fram til pessa hafa pau aldrei verið rannsökuð með skipulegum hætti.

Greinin skiptist í tvo hluta: Í peim fyrri er kannað með hvað hætti Guðmundur Daníelsson nýtir byggingarlag og hugmyndaheim skáldsögunnar Light in August eða Ljós í ágúst í Eldi, fyrsta bindi príleiksins Afjörðu ertu kominn. Í peim síðari er horft á rannsóknir Faulkner-fræðinga undanfarna tvo áratugi á pví hvers vegna verk Faulkners hafa höfðað sérstaklega til rithöfunda á svæðum sem staðið hafa höllum fæti í efnahagslegu og menningarlegu tilliti, ýmist innan heimalanda sinna eða gagnvart erlendu valdi. Spurt er hvort og pá hvernig Guðmundur Daníelsson nýti skáldsagnaformið til að fjalla um Ísland sem hjálendu eða nýlendu Dana. Fjallað er um skáldsöguna í samhengi eftirlendufræða og lögð sérstök áhersla á að greina pá mynd sem hún birtir af samspili valds og sjálfsmyndar með hliðsjón af páttum eins og stétt, kynpætti, kyni og fötlun.

Lykilorð: Guðmundur Daníelsson, William Faulkner, bókmenntasaga, heimsbókmenntir, eftirlendufræði, sjálfsmynd 


\section{A B S T R A C T \\ From South to North \\ William Faulkner and Guðmundur Daníelsson}

During the Forties, Icelandic novelist Guðmundur Daníelsson, wrote a trilogy called Out of the Ground Wast Thou Taken: Fire (1941), Sand (1942) and The Land beyond the Land (1944). Leading up to the publications Danílsson was vocal about the fact that he had read the works of American novelist William Faulkner. Later in life he would reveal that he read Faulkner in Norwegian translations and proudly acknowledged the direct line of descent he recognized between his own work and that of his American colleague. Until now no systematic analyzes has been done on the many parallels between their works.

The article is divided in two. The first half unfolds in which ways Danílsson reproduced structures, milieu, ideas, characters and events from Faulkner's novel Light in August in Fire. The latter half of the article situates Daníelsson's trilogy within a critical framework developed by Faulkner scholars in the last two decades where they have explored the relationship between Faulkner and the many writers who have engaged with him from the postcolonial world. Questions will be raised about if and then how Daníelsson deals with Iceland's postcolonial past in his novels, with a special emphasis on the connection between power and identity as it manifests itself in relation to, for example, class, race, gender and disability.

Keywords: Guðmundur Daníelsson, William Faulkner, literary history, world literature, postcolonial literary criticism, identity

\section{Haukur IngVarsson}

Rithöfundur og doktorsnemi í íslenskum bókmenntum

Hugvísindasviði Háskóla Íslands

Sæmundargötu 2

IS-101 Reykjavík, Ísland

haukuri@hi.is 
